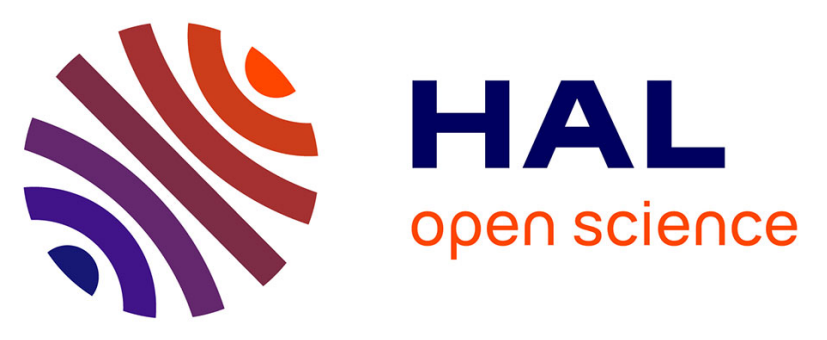

\title{
(Thia)calixarenephosphonic Acids as Potent Inhibitors of the Nucleic Acid Chaperone Activity of the HIV-1 Nucleocapsid Protein with a New Binding Mode and Multitarget Antiviral Activity
}

Nicolas Humbert, Lesia Kovalenko, Francesco Saladini, Alessia Giannini, Manuel Pires, Thomas Botzanowski, Sergiy Cherenok, Christian Boudier, Kamal Sharma, Eleonore Real, et al.

\section{- To cite this version:}

Nicolas Humbert, Lesia Kovalenko, Francesco Saladini, Alessia Giannini, Manuel Pires, et al.. (Thia)calixarenephosphonic Acids as Potent Inhibitors of the Nucleic Acid Chaperone Activity of the HIV-1 Nucleocapsid Protein with a New Binding Mode and Multitarget Antiviral Activity. ACS Infectious Diseases, 2020, 10.1021/acsinfecdis.9b00290 . hal-02493003

\section{HAL Id: hal-02493003 \\ https://hal.science/hal-02493003}

Submitted on 16 Dec 2020

HAL is a multi-disciplinary open access archive for the deposit and dissemination of scientific research documents, whether they are published or not. The documents may come from teaching and research institutions in France or abroad, or from public or private research centers.
L'archive ouverte pluridisciplinaire HAL, est destinée au dépôt et à la diffusion de documents scientifiques de niveau recherche, publiés ou non, émanant des établissements d'enseignement et de recherche français ou étrangers, des laboratoires publics ou privés. 
1 (Thia)calixarenephosphonic acids as potent inhibitors of the 2 nucleic acid chaperone activity of the HIV-1 nucleocapsid 3 protein with a new binding mode and multi-target antiviral activity

Nicolas Humbert ${ }^{1 \S}$, Lesia Kovalenko ${ }^{1,2 \S}$, Francesco Saladini ${ }^{3}$,Alessia Giannini ${ }^{3}$, Manuel Pires ${ }^{1}$, Thomas Botzanowski ${ }^{4}$, Sergiy Cherenok ${ }^{5}$, Christian Boudier ${ }^{1}$, Kamal K. Sharma ${ }^{1}$, Eleonore Real ${ }^{1}$, Olga A. Zaporozhets $^{2}$, Sarah Cianférani ${ }^{4}$, Carole Seguin-Devaux ${ }^{6}$, Federica Poggialini ${ }^{7}$, Maurizio Botta $^{7}$, Maurizio Zazzi ${ }^{3}$, Vitaly I. Kalchenko ${ }^{5}$, Mattia Mori ${ }^{7}$, Yves Mély ${ }^{1 *}$

1Laboratoire de Bioimagerie et Pathologies, UMR 7021 CNRS, Université de Strasbourg, Faculté de Pharmacie, 74 route du Rhin, 67401 Illkirch, France

2Department of Chemistry, Taras Shevchenko National University of Kyiv, 01601 Kyiv, Ukraine

3Department of Medical Biotechnologies, University of Siena, viale Mario Bracci n.16, 53100 Siena, Italy

4Laboratoire de Spectrométrie de Masse BioOrganique, IPHC UMR 7178 CNRS, Université de Strasbourg, 67000 Strasbourg, France

5Institute of Organic Chemistry, National Academy of Science of Ukraine, Murmanska str., 5, Kyiv 02660, Ukraine

6 Department of Infection and Immunity, Luxembourg Institute of Health, 29 rue Henri Koch, L-4354 Esch-sur-Alzette, Luxembourg

7Department of Biotechnology, Chemistry and Pharmacy, Department of Excellence 2018-2022

Università degli Studi di Siena, via Aldo Moro 2, I-53019 Siena, Italy

$\S \mathrm{NH}$ and LK equally contributed to this work

* To whom correspondence should be addressed. Tel: +33 (0)3 688542 63, Fax: +33 (0)3 688543 13. E-mail address: yves.mely@unistra.fr

\section{ABSTRACT}

The nucleocapsid protein (NC) is a highly conserved protein that plays key roles in HIV-1 replication through its nucleic acid chaperone properties mediated by its two zinc fingers and basic residues. NC is a promising target for antiviral therapy, particularly to control viral strains resistant to currently available drugs. Since calixarenes with antiviral properties have been described, we explored the ability of calixarene hydroxymethylphosphonic or sulfonic acids to inhibit NC chaperone properties and exhibit antiviral activity. By using fluorescence-based assays, we selected four calixarenes inhibiting $\mathrm{NC}$ chaperone activity with sub-micromolar $I C_{50}$ values. These compounds were further shown by mass spectrometry, isothermal titration calorimetry and fluorescence anisotropy to bind $\mathrm{NC}$ with no zinc ejection, and to compete with nucleic acids for the binding to $\mathrm{NC}$. Molecular dynamic simulations further indicated that these compounds interact via their phosphonate or sulfonate groups with the basic surface of NC, but not with the hydrophobic plateau at the top of the folded fingers. Cellular studies showed that the most soluble compound CIP201 inhibited the infectivity of wild-type and drug-resistant HIV-1 strains at low micromolar concentration, primarily targeting the early steps of HIV-1 replication, and notably the entry step. Moreover, CIP201 was also found to inhibit the flipping and polymerization activity of reverse transcriptase. Calixarenes form thus a class of non-covalent NC inhibitors, endowed with a new binding mode and multi-target antiviral activity.

Keywords: Nucleocapsid protein, HIV-1, Fluorescence, calixarenes, $\mathrm{NC}$ inhibitors

\section{INTRODUCTION}


1 During the last two decades, the number of drugs acting as 2 inhibitors of entry/fusion, reverse transcription, integration, 3 and protease cleavage developed to fight HIV disease has 4 gradually increased. Though being endowed with efficient 5 antiviral activity, all these compounds select for resistant 6 strains, as a result of the ability of HIV-1 to rapidly mutate ${ }^{1}$.

7 Even in the classical treatment scheme, namely the Highly

8 Active Anti-Retroviral Therapy (HAART), which combines

9 anti-retroviral drugs of different classes, treatment failures

10 due to drug resistance are still observed.

11 Thus, new compounds targeting novel and highly conserved

12 viral targets such as the nucleocapsid protein (NC) could be

13 helpful to limit or prevent the emergence of drug resistance.

14 NC exhibits a chaperone activity which enables the structural

15 rearrangement of nucleic acids (NAs) into their most stable

16 conformation. This activity relies on the ability of NC to bind

17 and dissociate rapidly from its NA targets, to destabilize

18 moderately stable NA secondary and tertiary structures and to

19 promote the annealing of complementary NA sequences ${ }^{2-5}$.

20 This NC activity is thought to be critical in the reverse

21 transcription process, where NC likely chaperones the

22 annealing of the primer tRNA to the primer binding site (PBS)

23 and the two strand transfers that are required for the synthesis

24 of the proviral DNA by reverse transcriptase ${ }^{6,7}$. NC is a small

25 basic protein that binds with high affinity $\left(10^{13}-10^{14} \mathrm{M}^{-1}\right)^{8}$

26 two zinc ions on two strictly conserved finger motifs (CCHC)

27 through their cysteine and histidine residues (Figure 1a).Upon

28 zinc binding, the NC protein adopts its functional folding

29 leading to the formation at the top of the folded fingers of a

30 hydrophobic plateau that involves the amino acids Val13,

31 Phe16, Thr24, Ala25, Trp37, Gln45 and Met46 ${ }^{9-14}$. This

32 plateau is critical for interaction with target NAs, notably

33 through a stacking of the $\operatorname{Trp} 37$ residue with the

34 nucleobases ${ }^{15-17}$. This key role of the plateau is further

35 illustrated by the fact that single mutation of any of its residues

36 results in non-infectious viral particles ${ }^{18}$.

Due to its key functions in HIV-1 replication and its high conservation, $\mathrm{NC}$ appears as an ideal target for antiretroviral therapy. Several strategies, including zinc ejectors, noncovalent NC binders and noncovalent NA binders of different chemical classes (see Discussion section for more details) have been developed, but were not fully successful, due to low specificity or to limited antiviral activity or therapeutic index ${ }^{19-21}$. In order to develop new compounds directed against $\mathrm{NC}$, we have focused our interest on calixarenes, a large family of macrocyclic aromatic compounds bearing phenolic groups, widely used in supramolecular chemistry ${ }^{22,23}$. Calixarenes are rigid vase-like macrocycles with a well-established chemistry. These molecules can be obtained through accessible and relatively cheap organic synthesis routes, which also allow the versatile functionalization of their macrocyclic core ${ }^{24-26}$. Calixarenes are also receptors in supramolecular recognition studies ${ }^{27,28}$ that can bind and/or host small molecules through their cavity ${ }^{29,30}$ making them suitable for drug delivery purposes. ${ }^{31-}$ 33. Calixarenes have been investigated among others as biologically-active molecules in a number of applications, and are recently emerging as candidate therapeutics against multiple diseases ${ }^{34-36}$. However, their mechanism of action is generally poorly elucidated, so that calixarenes are mostly used as tool compounds in chemical biology studies.

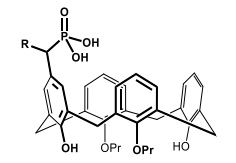

$\mathrm{C} 131 \mathrm{R}=\mathrm{OH}$ $\mathrm{C} 131 \mathrm{R}=\mathrm{OH}$
$\mathrm{C} 932 \mathrm{R}=\mathrm{P}(\mathrm{O})(\mathrm{OH})_{2}$

$$
\text { b }
$$

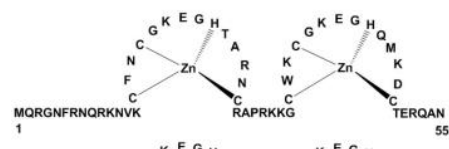

a
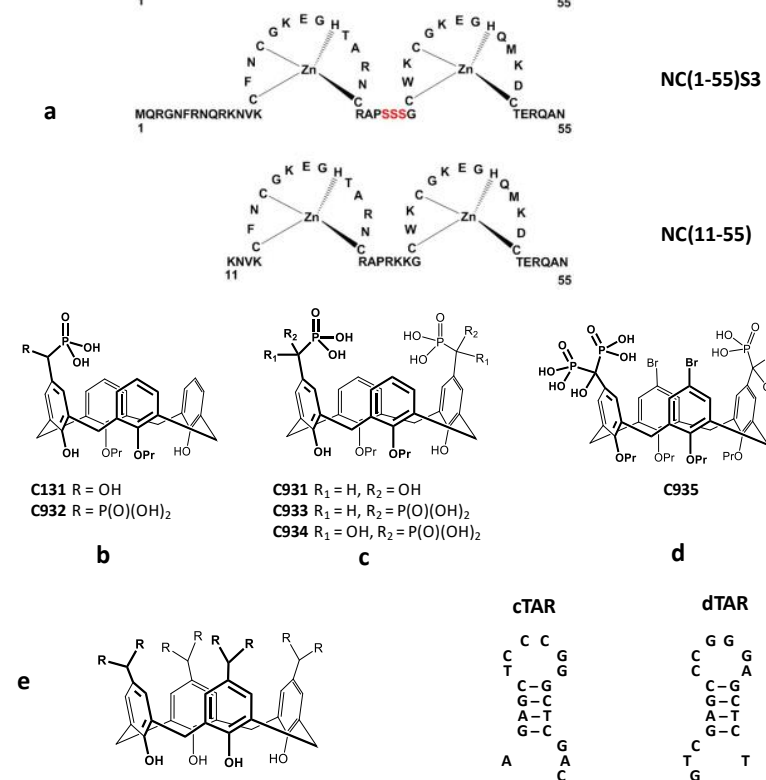

C931 $\mathrm{R}_{1}=\mathrm{H}, \mathrm{R}_{2}=\mathrm{OH}$ C933 $R_{1}=H, R_{2}=P(O)(O H)_{2}$ C934 $\mathrm{R}_{1}=\mathrm{OH}, \mathrm{R}_{2}=\mathrm{P}(\mathrm{O})(\mathrm{OH})_{2}$

C

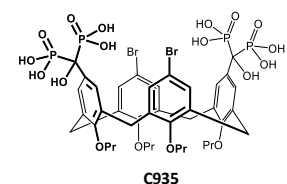

C145 R $=\mathrm{P}(\mathrm{O})(\mathrm{OH})(\mathrm{ONa})$

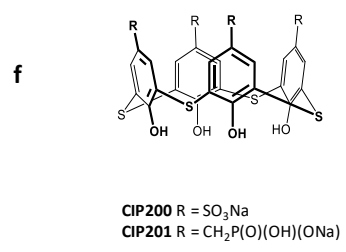

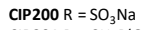
CIP201 $\mathrm{R}=\mathrm{CH}_{2} \mathrm{P}(\mathrm{O})(\mathrm{OH})(\mathrm{ONa})$

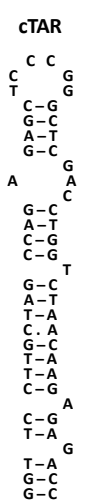
dTAR

Figure 1. NC peptides (a), calixarene compounds (b to f), and cTAR and dTAR oligonucleotides used in this study (g).

88 In this manuscript, we tested the ability of a series of 89 calixarene hydroxymethylphosphonic or sulfonic acids 90 (Figure 1b-f) to interact with NC and inhibit the binding of 
1 this protein to its target nucleic acids, preventing the 2 promotion of the destabilization and annealing of the 3 complementary sequences. Molecular modelling and 4 mutational studies indicated that calixarenes exhibit a new 5 binding mode where their phosphonate or sulfonate groups 6 interact with the basic surface of NC. The antiviral activity 7 and cellular cytotoxicity of the most efficient compound were 8 tested using HIV pseudoviruses, as well as replication9 competent wild-type (WT) and drug-resistant strains. This 10 compound was also tested in humanized mice infected with 11 HIV-1. Finally, the mechanism of action of this calixarene

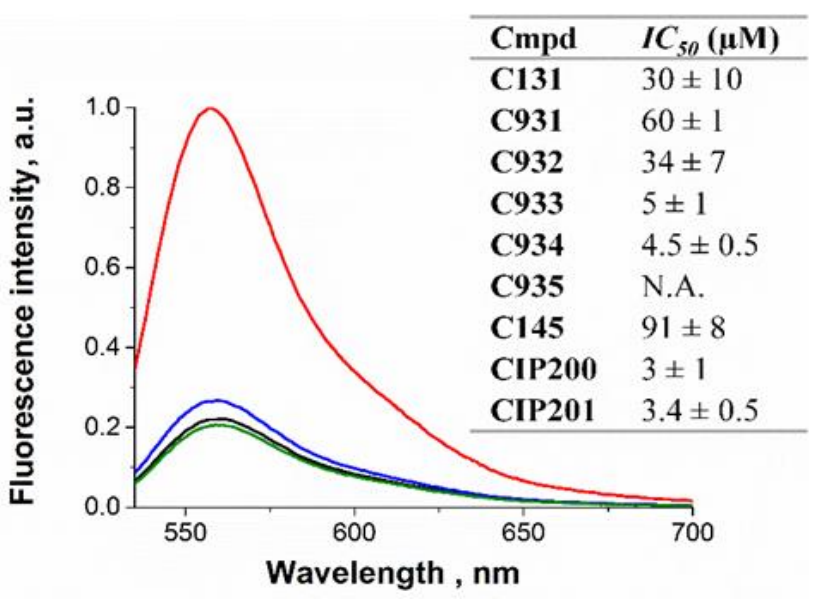

Figure 2. Inhibition of the NC(11-55)-induced cTAR destabilization by the calixarenes. Emission spectra of Rh6G-5'59 cTAR-3'-Dabcyl $(0.1 \mu \mathrm{M})$ were recorded in the absence (black) 60 and in the presence of $1 \mu \mathrm{M} \mathrm{NC}(11-55)$ before (red) and after 61 addition of $10 \mu \mathrm{M}$ (blue) or $100 \mu \mathrm{M}$ (green) CIP201. Buffer: 25 $62 \mathrm{mM}$ Tris $(\mathrm{pH}=7.5), 30 \mathrm{mM} \mathrm{NaCl}$ and $0.2 \mathrm{mM} \mathrm{MgCl}$. 63 Temperature: $20^{\circ} \mathrm{C}$. Excitation wavelength was $520 \mathrm{~nm}$. The 64 DMSO concentration was less than $2 \% \mathrm{v} / \mathrm{v}$ for all experiments. 65 The $I C_{50}$ values for the inhibition of NC(11-55)-induced cTAR 66 destabilization by the tested calixarenes are shown in the table. 67 N.A. $=$ Not Active
In contrast, no fluorescence change was induced by $\mathrm{C} 935$, indicating that it is unable to inhibit the $\mathrm{NC}(11-55)$-induced destabilization of cTAR. Notably, this compound differs from the other tested calixarenes by the fact that it possesses four propyl chains at the lower rim and two bromine substituents at the upper rim of the calixarene core. Assuming that the $\mathrm{OH}$ groups may be solvent exposed when calixarenes are bound to $\mathrm{NC}^{60}$, the $\mathrm{O}$-propyl chains become then unfavorably solvent-exposed. Moreover, the two bromine substituents may sterically hinder the inclusion of NC residues in the calixarene central core cavity or form a steric obstacle for the binding of $\mathrm{C} 935$ to the NC. Determination of the $I C_{50}$ values revealed that the other tested calixarenes could be divided into two classes (Figure 2, table). The first class comprising the four most active compounds (C933, C934, CIP200 and CIP201) is characterized by $I C_{50}$ values in the range $3-5 \mu \mathrm{M}$, close to the concentration of the NC peptide used in the assay. The second class (C131, C932, C145 and C931) is characterized by $I C_{50}$ values in the range $40-90 \mu \mathrm{M}$ and is thus far less efficient. Based on the difference in activities of the two classes, we focused our next efforts only on the compounds of the first class.

In order to confirm the ability of the four selected compounds to inhibit the NC chaperone properties, we checked their effect on the $\mathrm{NC}(11-55)$-promoted cTAR/dTAR annealing reaction (Figure 3), which relies on both the nucleic acid destabilizing and aggregating activities of $\mathrm{NC}^{61,62}$. We used in this test a cTAR sequence labelled with Alexa488 (fluorophore) and Dabcyl (quencher) at its 5' and 3' ends, respectively. In the absence of $\mathrm{NC}$, the fluorescence signal is low (Figure $3 \mathrm{a}$ ) due to the close proximity of both cTAR ends and the strong fluorescence quenching of the Alexa488 emission by the Dabcyl group. Of note, Alexa 488 was preferred to Rh6G, due to its lower tendency to bind to 
1 calixarenes at the high concentrations used in this assay (data 2 not shown). After addition of NC(11-55) at 8 eq, we observed 3 an increase of the fluorescence signal as a result of the 4 destabilization of cTAR by NC(11-55) (Figure $3 a)^{56}$. A further 5 increase in the fluorescence signal was observed when both 6 NC-coated sequences were mixed together in order to allow 7 the annealing reaction to proceed (Figure $3 \mathrm{a}$ and b). Real-time 8 annealing kinetics were monitored in pseudo-first order 9 conditions by following the increase of the Alexa488

10 fluorescence at $519 \mathrm{~nm}$. The same plateau was reached in the 11 absence and in the presence of calixarenes, indicating that the 12 same final product (extended duplex) was formed. However, 13 the reaction was slowed down in the presence of all four 14 selected calixarenes (Figure 3b), clearly indicating that they 15 efficiently counteract the NC-chaperoned annealing reaction. 16 The kinetic traces were fitted using ${ }^{61,63}$ :
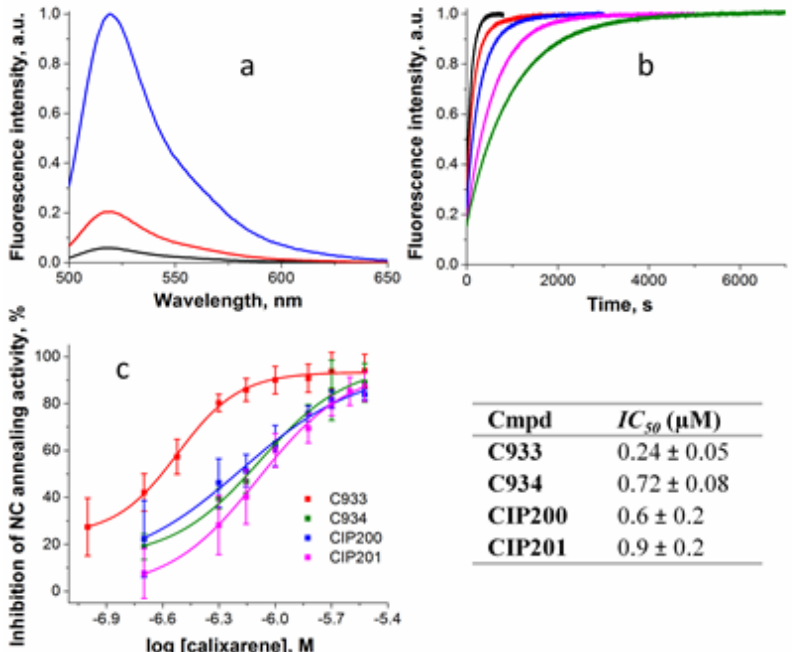

\begin{tabular}{ll}
\hline Cmpd & $I C_{50}(\boldsymbol{\mu M})$ \\
\hline C933 & $0.24 \pm 0.05$ \\
C934 & $0.72 \pm 0.08$ \\
CIP200 & $0.6 \pm 0.2$ \\
CIP201 & $0.9 \pm 0.2$ \\
\hline
\end{tabular}

$$
I(t)=I_{F}-\left(I_{F}-I_{0}\right) e^{-k_{o b s}\left(t-t_{0}\right)}
$$

where $t_{0}$ is the dead time, $k_{\mathrm{obs}}$ is the observed kinetic rate constant, and $I_{0}$ and $I_{\mathrm{F}}$ are the fluorescence intensities before dTAR addition and at completion of the reaction, respectively. $\mathrm{NC}$ annealing activity was calculated as the ratio $k_{\mathrm{obs}} / k_{\mathrm{obs} 0 \text {, }}$ where $k_{\text {obs }}$ and $k_{\text {obs } 0}$ are the kinetic rate constants in the presence and in the absence of calixarenes, respectively. $I C_{50}$ values were obtained by fitting to equation (4) the variation of the percentages of inhibition $(\%$ inh $=100-\%$ of $\mathrm{NC}$ annealing activity) as a function of the concentration of calixarene (Figure $3 \mathrm{c}$ ). The $I C_{50}$ values were in the submicromolar range, up to 10 times lower than those obtained for the destabilizing activity (Figure 2, table). The lowest value was observed for C933, which was about two to three times more active than the other three compounds (Figure 3, table).

Figure 3. Inhibition of $\mathrm{NC}(11-55)$-promoted cTAR/dTAR annealing reaction by selected calixarenes. (a) Fluorescence spectra of $10 \mathrm{nM}$ Alexa488-5'-cTAR-3'-Dabcyl in the absence (black line) and in the presence of $80 \mathrm{nM}$ of NC (11-55) (red line) and after annealing with $100 \mathrm{nM}$ of dTAR in the presence of 800 $\mathrm{nM}$ of NC(11-55) (blue line). Excitation was at $480 \mathrm{~nm}$. Buffer: $25 \mathrm{mM}$ Tris $(\mathrm{pH}=7.5), 30 \mathrm{mM} \mathrm{NaCl}$ and $0.2 \mathrm{mM} \mathrm{MgCl}_{2}$. Temperature: $20{ }^{\circ} \mathrm{C}$. (b) Effect of CIP201 on the NC-promoted cTAR/dTAR annealing reaction. Kinetic traces of the annealing

\section{8}

reaction in the absence of CIP201 (black) and in the presence of $0.5 \mu \mathrm{M}$ (red), $1 \mu \mathrm{M}$ (blue), $2 \mu \mathrm{M}$ (magenta) and $2.5 \mu \mathrm{M}$ (green) of CIP201. The kinetic traces were normalized. Excitation was at $480 \mathrm{~nm}$. Emission was recorded at $519 \mathrm{~nm}$. (c) Inhibition of the NC(11-55)-promoted cTAR/dTAR annealing reaction as a function of the concentration of C933 (red), C934 (green), CIP200 (blue), and CIP201 (magenta). The curves were fitted to equation (4). The concentration of DMSO was less than $2 \% \mathrm{v} / \mathrm{v}$. Table: $I C_{50}$ values for the inhibition of the NC(11-55)-promoted cTAR/dTAR annealing reaction by the tested calixarenes

Thus, the selected calixarenes inhibit efficiently both the nucleic acid destabilization and aggregation components of $\mathrm{NC}(11-55)$ chaperone activity.

\section{Binding of calixarenes to NC}

To determine whether the inhibitory activity observed in Figures 2 and 3 resulted from the direct binding of the calixarenes to $\mathrm{NC}(11-55)$ and not from zinc ejection, we used non-denaturing mass spectrometry for $\mathrm{NC}(11-55)$ in the absence or presence of a 10-fold molar excess of C933 or C934(Figure 4).

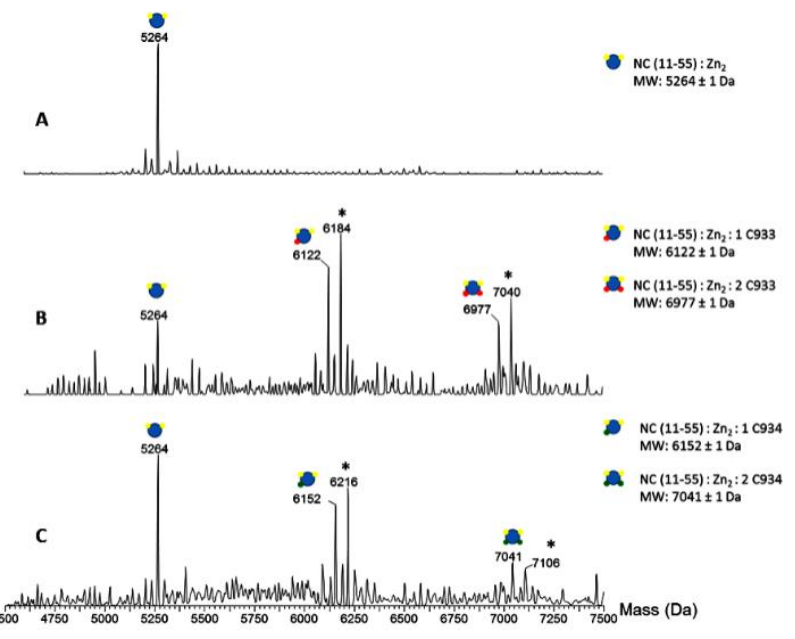

Figure 4. Binding of C933 and C934 to NC(11-55) monitored by non-denaturing mass spectrometry. Deconvoluted mass spectra in non-denaturing conditions of $20 \mu \mathrm{M} \mathrm{NC}(11-55)$ in $50 \mathrm{mM}$ $\mathrm{AcONH}_{4}$ at $\mathrm{pH} 7.0$ in the absence (A) or in the presence of 200 $\mu \mathrm{M}$ of $\mathrm{C} 933$ (B) or C934 (C) in $1 \%$ DMSO. * $\left[\mathrm{M}+\mathrm{CH}_{3} \mathrm{COO}\right]$ adduct. Experimental mass of each observed complex is given at the right part of the spectrum.

As previously described ${ }^{56,64-66}, \mathrm{NC}(11-55)$ is detected in its zinc-bound form with a measured mass of $5264 \pm 1 \mathrm{Da}$ (Figure 4A). In the presence of C933 (Figure 4B), signals corresponding to free $\mathrm{NC}(11-55)$ (with its $2 \mathrm{Zn}^{2+}$ ions) as well as to $1: 1$ and 1:2 NC(11-55):C933 complexes are detected. No peak corresponding to zinc-free $\mathrm{NC}(11-55)$ or zinc-free $\mathrm{NC}(11-55)$ :C933 species is detected, indicating that C933 binding occurs without zinc ejection. Similar results were obtained with C934, for which 1:1 and 1:2 NC(11-55):C934 complexes were detected along with free NC(11-55) (Figure 4C). Again no zinc-free peptide species were detected, demonstrating the absence of zinc ejection upon C934 binding to NC(11-55). Similar experiments were performed with CIP200 or CIP201, but led to weak MS signals not suitable 
1 for interpretation (data not shown), due either to lower 2 ionization efficiencies of CIP200 and CIP201 in electrospray 3 or neutralization of the charges of the resulting complexes. 4 Altogether non-denaturing MS analysis clearly indicates that 5 C933 or C934 binds to NC(11-55) but does not induce zinc 6 ejection.

7 The absence of zinc ejection with CIP200 and CIP201 was 8 checked by monitoring the time-dependence of their 9 inhibition of the NC(11-55)-induced cTAR destabilization. A

Table 1. Thermodynamic parameters for the binding of calixarenes to NC peptides.

\begin{tabular}{|l|c|c|c|c|}
\hline Cmpd & $N C$ & $\begin{array}{c}K_{\mathrm{d}} \\
(\mu \mathrm{M})\end{array}$ & $\begin{array}{c}\Delta H \\
\left(\mathrm{kcal}^{\mathrm{mol}}{ }^{-1}\right)\end{array}$ & $\begin{array}{c}\Delta \mathrm{S} \\
\left(\mathrm{cal}^{\mathrm{mol}}{ }^{-1} . \mathrm{K}^{-}\right. \\
1\end{array}$ \\
\hline C933 & $11-55$ & $0.7 \pm 0.2$ & $-3.8 \pm 0.5$ & $15 \pm 2$ \\
& $1-55$ & $0.15 \pm 0.1$ & $-4.4 \pm 0.3$ & $16 \pm 1$ \\
\hline C934 & $11-55$ & $1.8 \pm 0.6$ & $-2.8 \pm 0.3$ & $17 \pm 2$ \\
& $1-55$ & $0.12 \pm 0.1$ & $-2.5 \pm 0.2$ & $23 \pm 2$ \\
\hline CIP200 & $11-55$ & $2 \pm 1$ & $-5 \pm 2$ & $8 \pm 3$ \\
& $1-55$ & $0.7 \pm 0.1$ & $-3.1 \pm 0.1$ & $17.7 \pm 0.5$ \\
\hline CIP201 & $11-55$ & $1.1 \pm 0.5$ & $-5.7 \pm 0.9$ & $8 \pm 2$ \\
& $1-55$ & $0.2 \pm 0.1$ & $-7.3 \pm 0.4$ & $5.5 \pm 0.3$ \\
& $(1-55) \mathrm{S} 3$ & $1.7 \pm 0.2$ & $-4.7 \pm 0.9$ & $10 \pm 3$ \\
\hline
\end{tabular}

To investigate the contribution of the strong basic N-terminal domain of the peptide on calixarene binding, we performed ITC titrations with the full length NC. We found that $K_{\mathrm{d}}$ values are 3 to 15 times lower (Table 1) than those determined with the $\mathrm{NC}(11-55)$ mutant, suggesting that the basic $\mathrm{N}$-terminal domain of NC significantly contributes to calixarene binding. Moreover, the basic residues between the two zinc fingers play an important role too in the binding of CIP201 to NC, as indicated by the about one order of magnitude change in the $K_{\mathrm{d}}$ value when these residues were replaced by Ser residues in the NC(1-55)S3 mutant (Table 1).

To provide further information on the binding process, the electrostatic and non-electrostatic binding contributions were determined from the variation of $K_{d}$ with the concentration of $\mathrm{Na}^{+}$ions ${ }^{67}$. The number $\mathrm{m}$ ' of ion pairs and the nonelectrostatic binding constant $K_{d}(1 \mathrm{M})$ between $\mathrm{NC}(11-55)$ and the calixarenes were derived from:

$\log K_{d}=\log K_{d}(1 M)+\psi_{N a^{+}} m^{\prime} \log \left[N a^{+}\right]$

The value of the fraction of $\mathrm{Na}^{+}$ions thermodynamically bound per negatively charged moiety, $\psi_{\mathrm{Na}^{+}}$, was assumed to be 0.71 as for single-stranded $\mathrm{DNA}^{67,68}$. The plots of $\log K_{\mathrm{d}}$ versus $\log [\mathrm{NaCl}]$ were found to be linear in the $10-100 \mathrm{mM}$ salt concentration range (Figure 5). Interestingly, the contribution of the non-electrostatic interactions deduced from the $K_{d}(1 \mathrm{M})$ values was found to be dominant, representing $80 \%$ to $90 \%$ of the binding energy at $30 \mathrm{mM}$ $\mathrm{NaCl}$. Moreover, the number m' of ion pairs between $\mathrm{NC}(11$ $55)$ and the calixarenes was about 1 in all the complexes. Of note, a similar distribution of electrostatic and nonelectrostatic contributions was observed for the binding of $\mathrm{NC}(12-53)$ to a small d(AACGCC) oligonucleotide ${ }^{13,69}$.

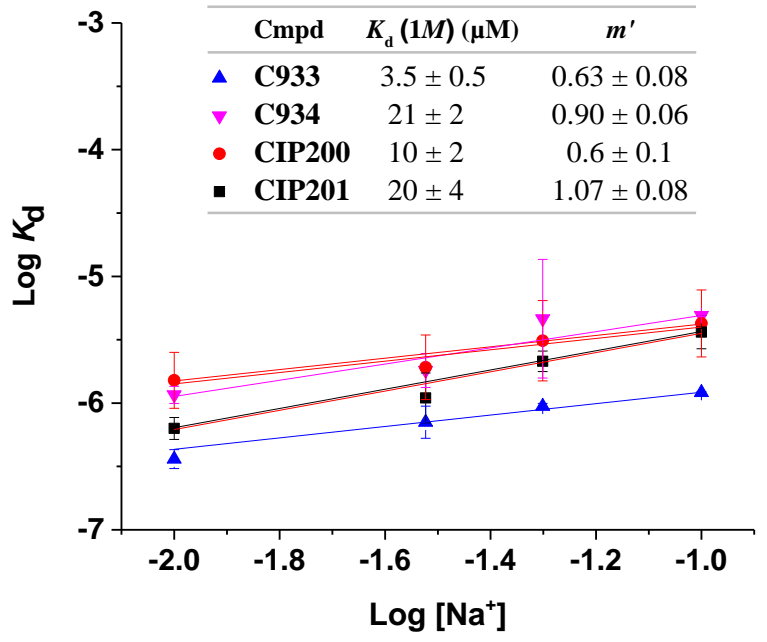

Figure 5. Dependence on $\mathrm{Na}^{+}$ion concentration of the equilibrium dissociation constant $K_{d}$ for the binding of calixarenes C933, C934, CIP200 and CIP201 to NC(11-55), as determined by ITC at $20^{\circ} \mathrm{C}$. The graph depicts the dependence of $\log K_{d}$ on $\log \left[\mathrm{Na}^{+}\right]$. Lines are least-squares fits of equation (2) to the experimental points. The table provides the equilibrium dissociation constant at $1 \mathrm{M} \mathrm{Na}^{+}\left(K_{d}(1 \mathrm{M})\right)$ and the numbers of ion pairs ( $\mathrm{m}$ ') between $\mathrm{NC}(11-55)$ and the calixarenes. Buffer: 25 $\mathrm{mM}$ Tris $(\mathrm{pH}=7.5), 0.2 \mathrm{mM} \mathrm{MgCl}$.

81

82 Finally, we performed fluorescence anisotropy titrations to 83 determine whether the calixarenes can compete with NAs for 84 the binding to $\mathrm{NC}(11-55)$. To this end, we titrated cTAR 85 labeled by tetramethylrhodamine, TMR-5' -cTAR, by NC(1186 55) in the absence and in the presence of calixarenes (Figure 
1 6). As expected, NC(11-55) was found to markedly increase 2 the fluorescence anisotropy of TMR-5' -cTAR, as a result of 3 the formation of the NC(11-55)/cTAR complex. All four 4 selected calixarenes were observed to shift the titration curves 5 toward higher $\mathrm{NC}(11-55)$ concentrations as compared to the 6 curve in the absence of calixarenes (Figure 6, black curve). 7 Thus, all four calixarenes compete with cTAR for the binding 8 to NC(11-55), which explains their ability to inhibit the NA 9 chaperone properties of the peptide. It should be noted that the

$10 \mathrm{C} 145$ used as negative control has, as expected, a marginal 11 impact on the binding of NC (11-55) with cTAR (Figure 6, 12 compare orange and black curves). Moreover, a control 13 experiment was performed to check both by ITC and 14 fluorescence titrations that calixarenes do not bind to cTAR 15 (Figure S5A and B). Thus, the calixarenes hinder the binding 16 of NC(11-55) to cTAR, only by their binding to the peptide.

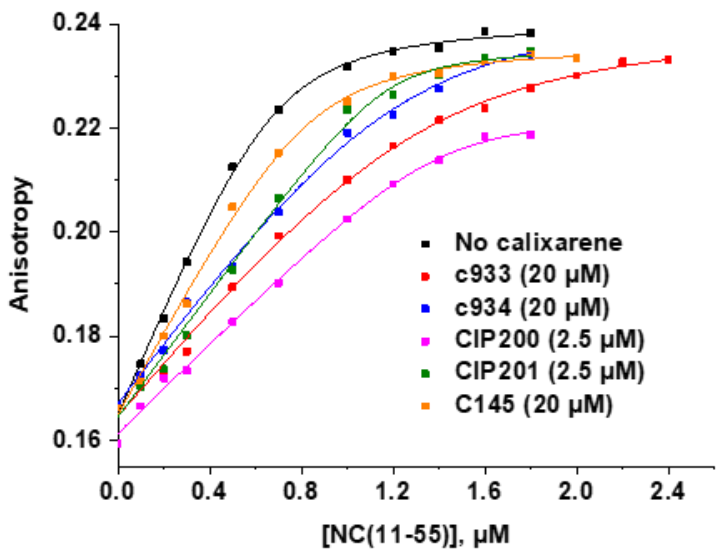

19 Figure 6. Binding of $\mathrm{NC}(11-55)$ to TMR-5' $-\mathrm{cTAR}$ in the

\section{8}

\section{9}

30 the absence (black) or in the presence of $20 \mu \mathrm{M}$ (red), $20 \mu \mathrm{M}$ C934 (blue), $2.5 \mu \mathrm{M}$ CIP200 (magenta) or $2.5 \mu \mathrm{M}$ CIP201 (green) or $20 \mu \mathrm{M} \mathrm{C1} 145$ (orange). Buffer: $25 \mathrm{mM}$ Tris pH
$7.5,30 \mathrm{mM} \mathrm{NaCl}$ and $0.2 \mathrm{mM} \mathrm{MgCl}_{2}$. Excitation wavelength was $550 \mathrm{~nm}$.

\section{Molecular dynamics simulations of NC/calixarene complexes}

To further rationalize our experimental data, and to characterize the binding mode of selected calixarenes to NC, we performed recognition experiments in silico through molecular dynamics (MD) simulations. This method was selected because of the complexity of calixarenes and the flexibility of NC, which render other approaches (such as molecular docking) ineffective towards this study. Each calixarene was placed at a non-binding distance from the NC surface (> $40 \AA$ ) in a box of explicit water molecules, and then unrestrained MD trajectories were produced for $0.5 \mu \mathrm{s}$ in the NPT ensemble. Using this approach, the four selected calixarenes were found to recognize and bind $\mathrm{NC}$, by interacting with the basic surface at the top of the zinc fingers. Similar to the previously reported complexes of calixarenes with isolated amino acids ${ }^{70,71}$ or proteins ${ }^{60}$, the recognition between calixarenes and the $\mathrm{NC}$ in silico is mostly driven by electrostatic forces between the calixarene phosphonate or sulfonate groups and basic NC residues (Figure 7 and Figure S6 in the supplementary data). In contrast, $\mathrm{OH}$ or O-propyl groups at the lower rim are exposed to the solvent and do not seem to contribute to the binding of the protein. Similarly, no interaction was observed with the specific hydrophobic pocket of NC or through inclusion of the side chain of the key residue Trp37 into the calixarene core. The formation of $\mathrm{NC} /$ calixarene complexes is rather fast in MD simulations, as observed by monitoring the distance between the target residue and the mass center of the carbons bearing the phosphonate or sulfonate groups (supplementary data, Figure S7). Moreover, the NC/calixarene complexes were found to be stable with time, since by analogy with other NC inhibitors ${ }^{66}$, we did not observe any dissociation of the complexes during MD simulation. 


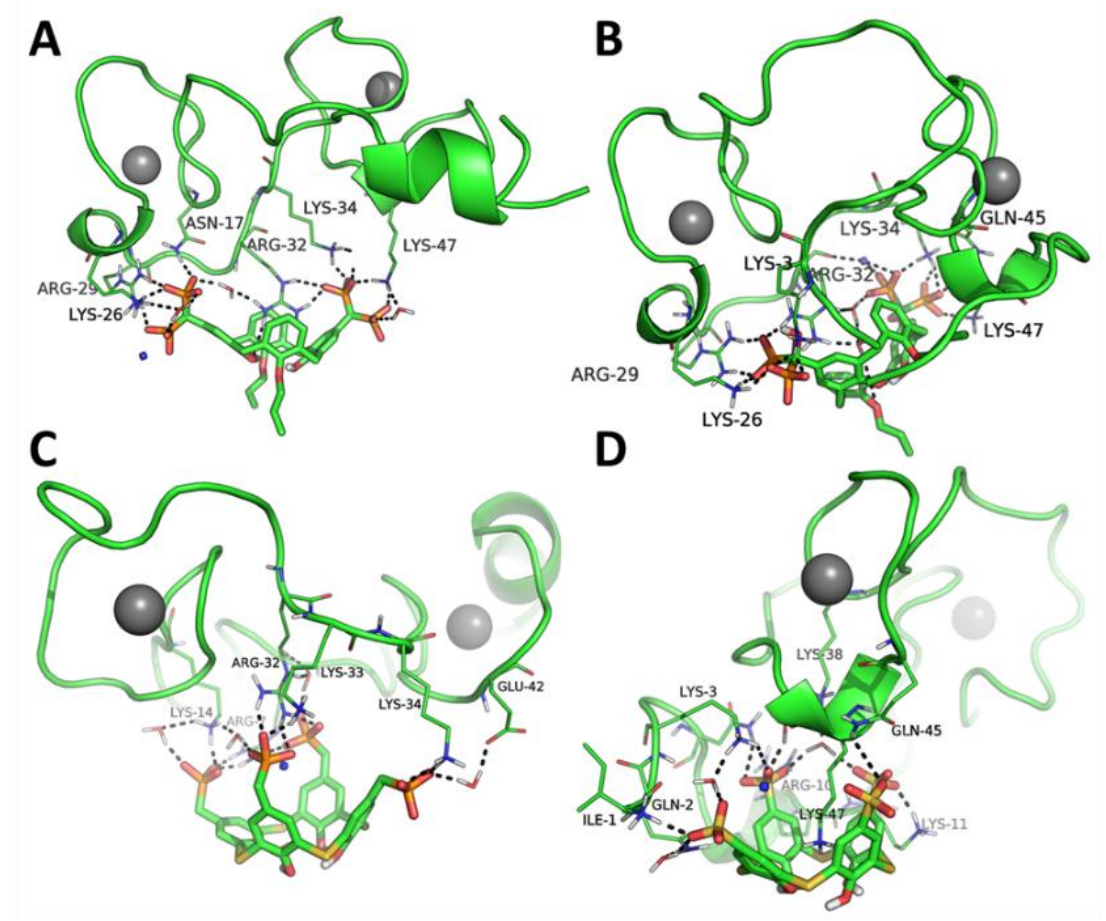

Figure 7. Binding mode of calixarenes to NC predicted by a recognition experiment performed along $0.5 \mu$ s of unrestrained MD simulations. The panels show the conformations of the most abundant clusters of MD frames for the complexes between NC and C933 (A), C934 (B), CIP201 (C) and CIP200 (D). The protein is shown as a green cartoon. Residues establishing polar contacts with calixarenes are shown as lines and are labeled. Bridging water molecules are shown as lines, calixarenes as sticks, $\mathrm{Zn}^{2+}$ ions as grey spheres, and $\mathrm{Na}^{+}$ions from the solvent as blue small spheres. Polar contacts between calixarenes and $\mathrm{NC}$ are shown as black dashed lines. The complexes were oriented to have the calixarene in the bottom part, with the upper rim projected towards the top of the panel.

As highlighted by the salt-dependence data of Figure 5, the Coulomb electrostatic contribution in the final complexes may be rather weak, due to the strong dielectric constant of the solvent that considerably lowers electrostatic forces. In fact, the $\mathrm{NC} /$ calixarene complexes are stabilized by cation- $\pi$ stacking ${ }^{72,73}$ and a number of $\mathrm{H}$-bonds established directly, or bridged by water molecules (Figure 7). In particular, phosphonate groups at the upper rim of calixarenes C933, C934, and CIP201 bind preferentially the side chain of Arg32 by both H-bond interactions and cation- $\pi$ stacking. The Arg32 residue is well included in the calixarene core of C 933 (Figure 7A), and partially included in the core of C934 (Figure 7B). In CIP201, the Arg32 residue is located at the upper rim of the calixarene molecule because the inner core is occupied by a $\mathrm{Na}^{+}$ion (Figure 7C), whereas CIP200 targets the side chain of Lys47, which is well included in the calixarene core (Figure 7D).

C933 and C934 proved to bind the $\mathrm{NC}$ in a highly comparable manner by interacting with Arg32, as well as with Lys26, Arg29, Lys34, and Lys47. C933 further interacts with Asn17 (Figure 7A), whereas C934 interacts with Lys3 and Gln45 (Figure 7B), this latter being also involved in the binding of other NC inhibitors ${ }^{65,66,74}$. Besides Arg32, CIP201 establishes H-bonds with Arg7, Lys14, Lys33, Lys34, and Glu42 (Figure 7C). In the case of CIP200, in addition to Lys47, the compound interacts with Ile1, Gln2, Lys3, Arg10, Lys11, Lys38, and Gln45 (Figure 7D).

Finally, to provide a structural explanation to the noticeable entropic effect observed by ITC (Table 1), the change of NC hydration associated to the binding of CIP200 was evaluated
103 along MD trajectories. The comparison of the solvation of NC

104 target residues in the free protein (Figure S8A) with that in the 105 complex (Figure S8B) clearly shows that CIP200 displaces a 106 large number of water molecules from solvent-exposed NC 107 residues such as for example Lys47, in full line with the 108 measured increase in entropy.

109 Overall, MD simulations suggest that the phosphonate and 110 sulfonate groups of calixarenes are responsible for NC 111 recognition through long-range electrostatic interactions and 112 for the stabilization of the final NC/calixarene complexes, 113 mainly through $\mathrm{H}-$ bond and cation- $\pi$ interactions with $\mathrm{NC}$ 114 basic residues. As a result, these molecules may inhibit NC by 115 competing with NAs for the binding to the protein and 116 occluding the accessibility to its hydrophobic pocket from the 117 solvent area.

118 To validity of the MD simulations is substantiated by the ITC 119 data with the $\mathrm{NC}(1-55) \mathrm{S} 3$ mutant where the three positively 120 charged basic residues $\left({ }^{32} \mathrm{RKK}^{34}\right)$ of the linker acting as a 121 binding site for CIP201 are replaced by non-charged Ser 122 residues. ITC titration of NC(1-55)S3 by CIP201 revealed an 123 about one order of magnitude decrease in affinity as compared 124 to NC, with a significant change in the balance between the 125 enthalpy and entropy contributions (Table 1). Indeed, we 126 observed a two-fold less favourable $\Delta \mathrm{H}$ value together with a 127 two-fold increase in the $\Delta \mathrm{S}$ value. These changes in $\Delta \mathrm{H}$ and $128 \Delta \mathrm{S}$ values strongly suggest that the binding of CIP201 is less 129 specific with the NC mutant as compared to $\mathrm{NC}^{75}$. Thus, the 130 binding data with $\mathrm{NC}(1-55) \mathrm{S} 3$ are fully in line with the MD 131 simulations and confirm the key role played by the ${ }^{32} \mathrm{RKK}^{34}$ 132 sequence in the binding of CIP201. 
2 Antiviral activity of CIP201 against wild-type 3 and drug-resistant HIV-1 strains

4 Next, our objective was to determine the antiviral activity of 5 the water soluble calixarene CIP201 acting as NC inhibitor. 6 Indeed, we selected this compound, as it remains highly 7 soluble in water (up to $100 \mathrm{mM}$ ) while the others calixarenes 8 were low soluble in aqueous solutions in the absence of 9 DMSO (solubility limits of C933, C934 and CIP200 were

Table 2. Antiviral activity and cytotoxicity of CIP201.

\begin{tabular}{ccccc}
\hline \multicolumn{3}{c}{ Anti pseudovirus assay $^{\mathrm{a}}$} & \multicolumn{2}{c}{ Antiviral assays ${ }^{\mathrm{d}}$} \\
\cline { 3 - 5 } & & $\begin{array}{c}\text { MonoCycle } \\
\text { assay }\end{array}$ & $\begin{array}{c}\text { BiCycle } \\
\text { assay }\end{array}$ \\
\hline $\mathrm{IC}_{50}{ }^{\mathrm{a}}$ & $\mathrm{CC}_{50}{ }^{\mathrm{b}}$ & $\mathrm{SI}^{\mathrm{c}}$ & $\mathrm{IC}_{50}{ }^{\mathrm{d}}$ & $\mathrm{IC}_{50}{ }^{\mathrm{d}}$ \\
$(\mu \mathrm{M})$ & $(\mu \mathrm{M})$ & & $(\mu \mathrm{M})$ & $(\mu \mathrm{M})$ \\
\hline $21 \pm 3$ & $>5000$ & $>230$ & $3.3 \pm 2$ & $1.7 \pm 0.2$
\end{tabular}

a Inhibition activity of CIP201 on the infection of Hela cells cellular assays. The first one being based on Hela cells infection with non-replicative pseudo-particles (antipseudovirus assay in Table 2) monitors only the inhibition of the early steps of infection. The second one being based on cell infection by a wild-type HIV virus (NL4-3) is sensitive to inhibition in either the early phase of HIV infection (MonoCycle) or both the early and late phases of HIV infection (BiCycle). In both the anti-pseudovirus and MonoCycle assays, CIP201 was found to inhibit HIV infection with $I C_{50}$ values of $3.3-21 \mu \mathrm{M}$ with comparable values in both MonoCycle and BiCycle assay, indicating that this compound inhibited mainly, if not only, the early phases of HIV replication. These $I C_{50}$ values were found to be close to the $I C_{50}$ values of the NC chaperone assays (Figures 2 and 3 ) and the $K_{\mathrm{d}}$ values (Table 1). These similar values determined by different independent experiments strongly suggest that the antiviral activity of CIP201 may be related to its ability to target NC. The cytotoxicity of CIP201 was very low $\left(C C_{50}>5 \mathrm{mM}\right)$, giving an excellent selectivity index for this compound. However, it cannot be excluded at this step that the low toxicity might be related to a limited cell permeability of the compound.

by viral pseudoparticles. $I C_{50}$ corresponds to the concentration at which the infection is decreased by $50 \%$. ${ }^{\mathrm{b}} \mathrm{C} \mathrm{C}_{50}$ : concentration required to cause $50 \%$ of cell death. ${ }^{\mathrm{c}}$ Selectivity index $S I=C C_{50} / I C_{50} .{ }^{\mathrm{d}}$ Inhibitory activities tested on HIV-1 wild-type reference strain NL4-3.

The compound CIP201 was then tested on a series of mutant strains resistant to reference protease inhibitors (PI, strain 11808), nucleoside reverse transcriptase inhibitors (NRTI, strain 7406), non-nucleoside reverse transcriptase inhibitors (NNRTI, strain 12231) and integrase inhibitors (INI, strain 11845) (Table 3). CIP201 showed an antiviral activity against

these representative resistant HIV-1 viral strains in the low micromolar range, similar to that against the wild-type virus (strain 114 i.e. NL4-3, Table 3). These data indicate that the resistance mutations to drugs currently employed in clinical practice do not affect the susceptibility to CIP201, reinforcing the conclusion that $\mathrm{NC}$ could be the main target of the calixarenes. Due to its favourable $I C_{50}$ values and low toxicity, CIP201 appears as a good starting point for the development of new anti-HIV agents.

Table 3. Antiviral activity of CIP201 against drug-resistant strains.

\begin{tabular}{ccc}
\hline${ }^{\text {a Strain }}$ & $\boldsymbol{I C}_{\boldsymbol{5 0}}(\boldsymbol{\mu M})$ & ${ }^{\text {b}}$ Fold Change \\
\hline $\mathbf{1 1 4}$ & $1.7 \pm 0.2$ & 1.0 \\
$(\mathbf{N L 4 - 3})$ & & 1.3 \\
$\mathbf{1 1 8 4 5}$ & $2.3 \pm 0.4$ & \\
$(\mathbf{I N I})$ & & 1.1 \\
$\mathbf{1 1 8 0 8}$ & $1.8 \pm 0.1$ & \\
$(\mathbf{P I})$ & & 0.6 \\
$\mathbf{1 2 2 3 1}$ & $1.0 \pm 0.5$ & \\
$(\mathbf{N N R T I})$ & & 0.9 \\
$\mathbf{7 4 0 6}$ & $1.5 \pm 0.3$ & \\
$(\mathbf{N R T I})$ & &
\end{tabular}

59 a Reference number of the drug resistant strains obtained 60 through the NIH AIDS Reagent Program 61 (ARP,www.aidsreagent.org). ${ }^{\text {b}}$ Ratio of the resistant virus 62 IC50 to wild-type reference virus IC50.

\section{Mechanism of action of calixarenes}

64 As CIP201 was found to be active in the early steps of HIV 65 replication, we performed complementary investigation to 66 further characterize its mode of action. As a first step, we 67 investigated the effects of CIP201 on the production of viral 68 nucleic acid intermediates. The data in Figure 8 suggests that inhibition of HIV replication occurred mainly during preintegration events. In particular, the amount of total HIV-1 DNA (Figure 8A) produced after reverse transcription (approximately $16 \mathrm{~h}$ post infection) was significantly decreased in presence of CIP201. This decrease was similar to that measured in the presence of rilpivirine (RPV), indicating an impairment of reverse transcription or earlier events. In contrast, CIP201 did not affect the levels of 2-LTR circles (Figure 8B). This absence of effect is in contrast with the approximately 3 times higher amount of 2-LTR circles observed with the integrase inhibitor raltegravir (RAL) as compared to "no drug" control culture. This suggests that CIP201 does not impair viral DNA integration. In addition, the levels of intracellular HIV-1 RNA were comparable to those measured in presence of RPV, reinforcing the hypothesis of an early inhibitory activity for CIP201 (Figure $8 \mathrm{C})$. 

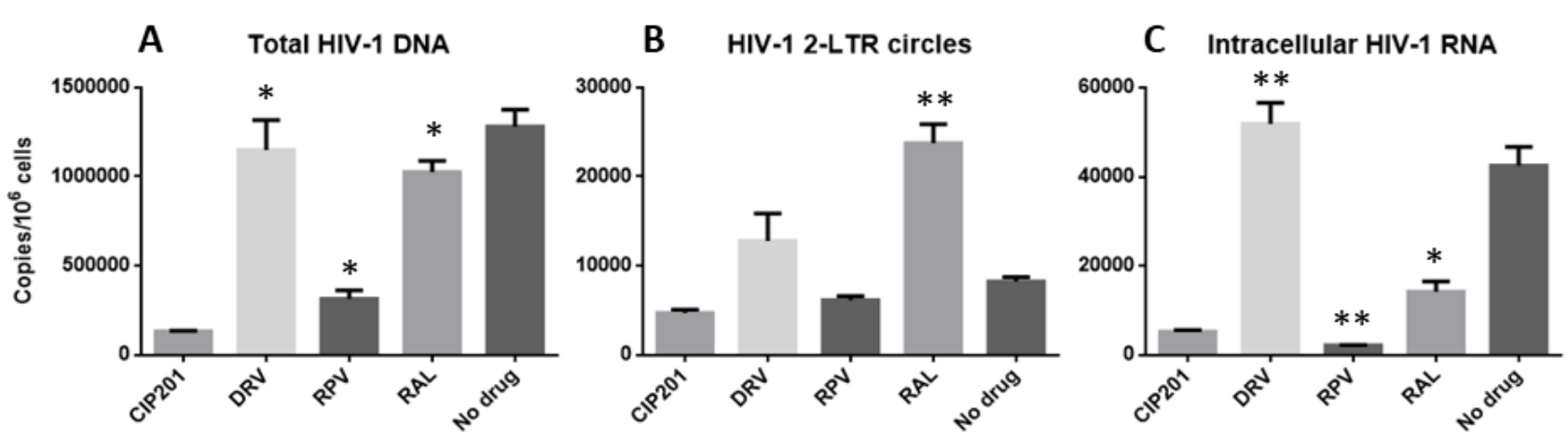

88

89

90

91

92

93

Figure 8. Quantification of HIV-1 nucleic acid intermediates produced in the presence of CIP201 (100 $\mu$ M), or reference compounds darunavir (DRV), rilpivirine (RPV), raltegravir (RAL) $(2 \mu \mathrm{M}$ each) or no drug. (A) Total HIV-1 DNA measured at 16 hours post infection. (B) HIV-1 2-LTR DNA circles and (C) Intracellular HIV-1 RNA measured at 30 hours post infection. Values are shown as means with standard deviation bars derived from two measurements. Pairwise comparisons between CIP201 and each reference drug were made by Student $\mathrm{t}$ test. *: $\mathrm{p}<0.05 ; * * \mathrm{p}<0.005$.

In a second step, since compound CIP201 was observed to possibly impair reverse transcription, we tested whether this compound could directly inhibit RT activity. Using a FRETbased assay previously developed in the laboratory ${ }^{76}$, CIP201 (Figure S9a) was found to strongly alter RT flipping and polymerisation activity, indicating it may directly target RT. Its effect was similar to that of Nevirapine, a non-nucleoside RT inhibitor (NNRTI) that binds non-competitively to RT allosteric sites ${ }^{77,78}$. By fitting the dependence of RT inhibition as a function of the concentration of CIP201 with equation (4), an $I C_{50}$ value of $0.9( \pm 0.1) \mu \mathrm{M}$ was determined for CIP201 (Figure S9b), as compared to $49( \pm 4) \mathrm{nM}$ for Nevirapine in
106 the same assay ${ }^{76}$. Altogether our data suggest that CIP201 107 may have multiple molecular targets in HIV-1. However, as 108 CIP201 is also active on RT resistant strains, it is believed that 109 RT is not a major target of CIP201 in cellular assays and/or 110 that CIP201 inhibits RT via a novel binding mode that is 111 different from that of the established inhibitors.

112 To further decipher the mode of action of CIP201, we used a 113 Multi-Dosing Time protocol to test its effect comparatively to 114 reference inhibitors of entry (maraviroc), RT (lamivudine and 115 didanosine) and integrase (raltegravir) (Table 4).

Table 4. IC50 values obtained in the Multi-Dosing Time protocol using the pseudotype virus assay.

\begin{tabular}{|l|c|c|c|c|c|}
\hline & \multicolumn{4}{|c|}{ Compounds IC } & \\
\hline \multicolumn{1}{|c|}{ CIP201 incubation } & $\begin{array}{c}\text { CIP20 } \\
1\end{array}$ & Maraviroc & Lamivudine & Didanosine & Raltegravir \\
\hline $\begin{array}{l}\text { Pre-incubation with the } \\
\text { cells before infection }\end{array}$ & Inactive & $4.5 \pm 0.8 \mathrm{nM}$ & Inactive & Inactive & Inactive \\
\hline $\begin{array}{l}\text { Incubation for 2 h during } \\
\text { HIV-1 infection. }\end{array}$ & $19 \pm 2 \mu \mathrm{M}$ & $5 \pm 2 \mathrm{nM}$ & $1.3 \pm 1 \mathrm{nM}$ & $99 \pm 6 \mathrm{nM}$ & $2 \pm 3 \mu \mathrm{M}$ \\
\hline Standard protocol for 48 h & $20 \pm 3 \mu \mathrm{M}$ & $7 \pm 3 \mathrm{nM}$ & $1.3 \pm 0.6 \mathrm{nM}$ & $6.4 \pm 0.9 \mathrm{nM}$ & $4 \pm 1 \mathrm{nM}$ \\
\hline $\begin{array}{l}\text { incubation for 2 h after } \\
\text { viral entry }\end{array}$ & $\begin{array}{c}\text { Residual } \\
\text { activity }\end{array}$ & $3 \pm 1 \mu \mathrm{M}$ & $0.6 \pm 0.4 \mathrm{nM}$ & $9 \pm 2 \mathrm{nM}$ & $1.2 \pm 1 \mathrm{nM}$ \\
\hline $\begin{array}{l}\text { Incubation for } 48 \mathrm{~h} \text { after } \\
\text { viral entry }\end{array}$ & $\begin{array}{c}\text { Residual } \\
\text { activity }\end{array}$ & $2.5 \pm 2 \mu \mathrm{M}$ & $1.3 \pm 0.7 \mathrm{nM}$ & $120 \pm 40 \mathrm{nM}$ & $4 \pm 3 \mathrm{nM}$ \\
\hline
\end{tabular}

$\mathrm{IC}_{50}$ values are expressed as a mean $\pm \mathrm{SD}$. Two independent experiments were performed in triplicate.

In the standard protocol, CIP201 was incubated with the cells for $2 \mathrm{~h}$ during spinoculation and then, again for $48 \mathrm{~h}$.

When CIP-201 was pre-incubated with the cells for 2 hours and then washed out before HIV-1 incubation, no effect was observed on virus infection, suggesting that CIP201 likely does not bind with high affinity to the plasma membrane in order to protect the cells against HIV-1 infection. In contrast, CIP201 protected U373-CD4-CCR5 cells against virus infection when incubated together with the pseudotyped viruses for $2 \mathrm{~h}\left(\mathrm{IC}_{50}=19 \pm 2 \mu \mathrm{M}\right)$ or in the standard protocol where CIP201 was added both during spinoculation (for $2 \mathrm{~h}$ ) and at $2 \mathrm{~h}$ post-infection (for $48 \mathrm{~h}$ ) $\left(\mathrm{IC}_{50}=20 \pm 3 \mu \mathrm{M}\right.$ ). Moreover, CIP201 showed only residual activity when incubated with cells $2 \mathrm{~h}$ post-infection (Figure S10 and Table
133 4). Thus, CIP201 resembles to the entry inhibitor maraviroc,

134 but differs from RT inhibitors that remain fully active when 135 provided for 2 or $48 \mathrm{~h}$ at $2 \mathrm{~h}$ post-infection. Therefore, our 136 data suggest that CIP201 mainly targets the HIV-1 entry step 137 during the first two hours of infection. The low activity of 138 CIP201 when provided $2 \mathrm{~h}$ after infection, in spite of its high 139 activity on NCp7 and RT in molecular assays, suggests that 140 CIP201 might not enter efficiently into cells. The lack of 141 activity on HIV-1 infection after cell pre-treatment wth 142 CIP201 and subsequent wash, confirms that CIP201 does not 143 enter efficiently into cells, and may primarily act by binding 144 to viral particles. Finally, its residual activity when added $2 \mathrm{~h}$ 145 after infection (Figure S10) may tentatively be attributed to 
1 CIP201 molecules that have been shuttled into cells through 2 viral particles docked on the cell surface, in order to inhibit 3 HIV-1 replication possibly by acting on RT and NCp7.

5 CIP201 activity in HIV-infected humanized NSG 6 mice

7 Finally, CIP201 was tested in humanized NSG mice ${ }^{79}$ and 8 compared with the triple regimen Triumeq (abacavir, 9 dolutegravir, lamivudine) on viral replication and CD4 10 depletion after 7 weeks of treatment. After 5 weeks of HIV 11 infection, although the mice have drunk the same volume of 12 sucralose solution among the three groups, we did not find any 13 effect of CIP201 on plasma viral load (Figure S10A) and on 14 the CD4/CD8 ratio (Figure S10B) after 6 weeks of treatment. 15 In contrast, the mice treated with Triumeq reached 16 undetectable viral load and restored CD4 cell count. The

\section{CONCLUSION}

affinity of calixarenes for $\mathrm{NC}$, we further showed that the binding of calixarenes C933, C934, CIP200 and CIP201 to $\mathrm{NC}(11-55)$ involved about 1 ion pair and that nonelectrostatic interactions represented $80 \%$ to $89 \%$ of the binding energy at $30 \mathrm{mM} \mathrm{NaCl}$. This suggests that long-range electrostatic interactions are likely required for recognition between the two interacting species, but as suggested by MD simulations, the complex is mainly stabilized by H-bonds, cation- $\pi$ interactions and water release. Calixarenes C933, C934, and CIP201 that bear phosphonate groups at the upper rim show a similar interaction pattern. They recognize and bind basic residues of the NC linker (and notably Arg32) by H-bond and cation- $\pi$ interactions, and establish a number of $\mathrm{H}$-bond contacts with basic residues at the top of zinc-fingers, a region of $\mathrm{NC}$ that is crucial for its biological functions. ${ }^{82,83}$ The key role of the basic residues of the NC linker in binding to CIP201 was clearly confirmed using a NC mutant where these residues were replaced by Ser residues $(\mathrm{NC}(1-55) \mathrm{S} 3$, Figure 1a). Different from the other active calixarenes, CIP200 is functionalized with sulfonate groups at the upper rim, and targets the Lys 47 by means of cation- $\pi$ interactions through inclusion of the residue's side chain in its aromatic core. CIP200 also interacts with a cluster of residues within the $\mathrm{N}$-terminal domain of $\mathrm{NC}$, suggesting that the binding site of calixarenes on $\mathrm{NC}$ may be modulated by specific functionalization at the upper rim of the aromatic core.

Importantly, the binding mode predicted for calixarenes was not observed before for any type of NC inhibitors. The main hypothesis that emerged by coupling computational with biophysical and biochemical data is that this new binding mode efficiently prevents $\mathrm{NC}$ to bind to its nucleic acid targets. Moreover, the water soluble compound CIP201 was found to inhibit replication of wild-type and drug-resistant HIV-1 strains in a cellular model at low micromolar concentration, by targeting the early steps of HIV-1 replication. Time of addition assays further revealed that CIP201 has low cell permeability, likely due to its high amount of negative charges, and mainly targets the viral entry step. In addition, the residual activity observed after the HIV1 entry step suggested that CIP201 molecules could have entered cells when bound to viral particles and exerted their antiviral activity on RT and $\mathrm{NCp} 7$ molecules. Both modes of action are fully consistent with the low levels of HIV-1 DNA and intracellular HIV-1 RNA measured in cells infected by HIV-1 in the presence of CIP201.

Finally, CIP201 showed low cytotoxicity that can be at least partly ascribed to the low cell permeability of the compound. The low toxicity of CIP201 was further confirmed on infected humanized mice, which showed no evidence of acute toxicity during the treatment. Therefore, CIP201 stands as a very interesting lead, since its efficacy in inhibiting HIV-1 replication is highly comparable to other $\mathrm{NC}$ inhibitors (Mori et al, Sancineto et al, Iraci et al). Unfortunately, CIP201 was found to be inactive in this animal model. This lack of efficacy in vivo was related to the low compound's concentration in blood and different organs, suggesting a high clearance and poor tissue distribution likely due to its highly polar nature ${ }^{99}$. 
entry step. CIP201 was also found to inhibit the nucleic acid chaperone activity of the HIV-1 NC as well as the flipping and polymerisation activity of RT in molecular assays. The inhibition of $\mathrm{NC}$ was predicted to result from the interaction of CIP201 via its phosphonate or sulfonate groups with the basic surface of NC, which blocks the binding of NC to its nucleic acid targets. This binding mode differs from that of most other noncovalent $\mathrm{NC}$ inhibitors that target the hydrophobic platform at the surface of the NC zinc fingers (Mori et al, 2015). Importantly, due to its low permeability the antiviral activity of this multi-target compound is certainly underestimated. Thus, CIP201 appears as a very promising candidate for the development of anti-HIV drug candidates targeting the NC.

However, efforts are still needed to further increase its efficacy and improve its ADME and pharmacokinetic properties. To this aim, hit-to-lead optimization of CIP201 could be driven by the necessity to tune the hydrophilichydrophobic balance in order to ensure a better pharmacokinetics profile and to enhance in vivo activity. This could be accomplished by chemical modifications at the lower (narrow) rim or the upper (wide) rim of the macrocycle. Interestingly, thiacalixarenes offer almost unlimited possibilities for chemical modifications, including the derivatization of the hydroxyl groups at the lower rim, or the four reactive para-positions of benzene rings at the upper rim by the inclusion of different functional groups with specific chemical or physicochemical features. In the specific case of CIP201, the phosphonate groups could be replaced by bioisosters or other negatively charged groups such as for instance the carboxylic acid, sulfone, triazole, and tetrazole rings. In addition, sulfur atoms can be oxidized to convert the thiacalixarenes into calixarene sulfoxides or calixarenes sulfone with four or six valent sulfur atoms respectively. Besides chemical modifications, conformational changes to the macrocyclic core can be designed in order to achieve optimal interaction with NC. Thanks to the accessible chemistry of calixarenes, and the reliable computational protocol developed in this work, a large number of thiacalixarene derivatives could be preliminarily screened and prioritized in silico for their interaction with $\mathrm{NC}$, although this will be the subject of future works.

\section{EXPERIMENTAL SECTION}

\section{Materials}

All solvents for spectroscopic measurements were from Sigma-Aldrich (Darmstadt, Germany). Acetonitrile was purchased from Sigma-Aldrich (Darmstadt, Germany) with high degree of purity for the HPLC analysis.

The synthesis and the characterization of the calixarenes used in this study are described in the supplementary information. Calixarenes C145 and CIP201 were directly solubilized in water while the other calixarenes were first dissolved in DMSO. Unless mentioned otherwise, experiments were carried out in Tris buffer $(25 \mathrm{mM}$ Tris- $\mathrm{HCl} \mathrm{pH} \mathrm{7.5,30 \textrm {mM }}$ $\mathrm{NaCl}$, and $0.2 \mathrm{mM} \mathrm{MgCl} 2)^{59}$. The percentage of DMSO was

\section{Oligonucleotides}

77 All unlabelled and labelled oligodeoxynucleotides (ODNs) 78 were synthesised and purified by IBA GmbH Nucleic Acids 79 Product Supply (Göttingen, Germany). Their concentrations 80 were determined by UV absorbance at $260 \mathrm{~nm}$. For the doubly 81 labelled cTAR, the 5' terminus was labelled with 682 carboxyrhodamine (Rh6G) or with Alexa Fluor 488 via an 83 amino linker with a six carbon spacer arm. The 3' terminus of 84 cTAR was labelled with 4-(4'85 dimethylaminophenylazo)benzoic acid (Dabcyl) using a 86 special solid support with the dye already attached. The singly 87 labelled cTAR was labelled with 88 carboxytetramethylrhodamine (TMR) at its 5' terminus. The 89 ODNs were purified by reverse-phase high performance 90 liquid chromatography (HPLC) and polyacrylamide gel 91 electrophoresis. Extinction coefficients at $260 \mathrm{~nm}$ of $5.15 \times$ $9210^{5} \mathrm{M}^{-1} \mathrm{~cm}^{-1}, 5.56 \times 10^{5} \mathrm{M}^{-1} \mathrm{~cm}^{-1}, 5.775 \times 10^{5} \mathrm{M}^{-1} \mathrm{~cm}^{-1}$, and 5.73 $93 \times 10^{5} \mathrm{M}^{-1} \mathrm{~cm}^{-1}$ were used to determine the concentration of 94 dTAR, TMR-5'-cTAR, Rh6G-5'-cTAR-3'-Dabcyl, and 95 Alexa488-5'-cTAR-3'-Dabcyl, respectively.

\section{6}

\section{Absorption and fluorescence spectroscopy}

Absorption spectra were recorded with a Cary 400 or a Cary 4000 spectrophotometer (Agilent). Fluorescence spectra and anisotropy measurements were recorded at $20^{\circ} \mathrm{C}$ with a Fluorolog or a Fluoromax 3 spectrofluorometer (Horiba Jobin-Yvon) equipped with a thermostated cell compartment. Excitation wavelengths were $520 \mathrm{~nm}$ for Rh6G-5'-cTAR-3'Dabcyl, $550 \mathrm{~nm}$ for TMR-5'-cTAR, and $480 \mathrm{~nm}$ for Alexa488-5' -cTAR-3'-Dabcyl. The spectra were corrected for dilution, buffer fluorescence and wavelength-dependent response of the optics and detectors.

To screen calixarenes (Cal), we used an assay in which we tested their ability to inhibit the NC-induced destabilization of cTAR $^{59}$. The percentage of inhibition (\% inh) obtained for each calixarene concentration was calculated with equation (3):

$$
\% \text { inh }=\frac{I_{(c T A R+N C)}-I_{(c T A R+N C+C a l)}}{I_{(c T A R+N C)}-I_{(c T A R)}} \times 100
$$


2 where $I_{(\mathrm{cTAR})}, I_{(\mathrm{cTAR}+\mathrm{NC})}$, and $I_{(\mathrm{cTAR}+\mathrm{NC}+\mathrm{Cal})}$ correspond to the 3 fluorescence intensity of cTAR alone, cTAR in the presence 4 of the NC(11-55)peptide, and cTAR in the presence of both $5 \mathrm{NC}(11-55)$ and calixarene, respectively. To determine the $I C_{50}$ 6 values, we plotted the percentage of inhibition against the 7 calixarene concentration $(C)$ and fitted it with a modified 8 version of the dose-response equation ${ }^{105}$ :

$$
\% \text { inh }=A_{1}+\frac{\left(A_{2}-A_{1}\right)}{1+10^{\left.\left(\log \left(I C_{50}\right)-\log (C)\right) \times p\right)}}
$$

(4)

where, $A_{1}$ and $A_{2}$ represent the percentage of inhibition in the absence and with saturating concentrations of calixarene, respectively. $I C_{50}$ represents the half maximal inhibitory concentration, and $p$ denotes the Hill coefficient.

Annealing kinetics were measured in pseudo-first order conditions by adding a 10-fold excess of unlabelled dTAR to the doubly labelled complementary sequence Alexa488-5'cTAR-3'-Dabcyl. Excitation and emission wavelengths were set at $480 \mathrm{~nm}$ and $519 \mathrm{~nm}$, respectively to monitor the Alexa 488 fluorescence. $\mathrm{NC}(11-55)$ was added at a 8:1 molar ratio to each reactant separately, and then the reaction was initiated by mixing the peptide-coated ODNs together. Calixarenes (C933, C934, CIP200 and CIP201) were added at different concentrations to monitor their ability to perturb the NCpromoted cTAR/dTAR annealing rate constants $k_{\text {obs. }}$ All fitting procedures were carried out with Origin 8.6 software using nonlinear least-squares methods and the LevenbergMarquardt algorithm.

\section{Mass spectrometry in non-denaturing conditions}

Electrospray ionization mass spectrometry (ESI-MS) analysis was performed in the positive ion mode on an electrospray time-of-flight mass spectrometer (LCT, Waters, Manchester, UK) equipped with an automated nanoESI source (TriversaNanomate, Advion, Ithaca, NY). Calibration of the instrument was performed using a $2 \mu \mathrm{M}$ horse heart myoglobin solution prepared in a mixture of water:acetonitrile (1:1) acidified with $1 \%$ of formic acid. MS data were acquired and analysed using the MassLynx 4.1 software (Waters, Manchester, UK). For mass spectrometry experiments in nondenaturing conditions, $\mathrm{NC}(11-55)$ was prepared in water with 2.2 molar equivalents of $\mathrm{ZnSO}_{4}$ and the concentration was measured using an extinction coefficient of $5700 \mathrm{M}^{-1} \mathrm{~cm}^{-1}$ at $280 \mathrm{~nm}$. Before use, the protein was buffered with $50 \mathrm{mM}$ ammonium acetate $\left(\mathrm{AcONH}_{4}\right)$ at $\mathrm{pH}$ 7.0. $\mathrm{NC}(11-55)$ protein $(20 \mu \mathrm{M})$ was incubated with $200 \mu \mathrm{M}$ of calixarenes(10 fold excess, $1 \%$ of DMSO v/v in the final volume) at $20{ }^{\circ} \mathrm{C}$ for 15 $\mathrm{min}$, before recording the mass spectra. In order to balance the weak ionization due to the presence of DMSO, the analyses under non-denaturing conditions were carried out with an accelerating voltage $(\mathrm{Vc})$ of $100 \mathrm{~V}$, and the pressure in the first pumping stage (backing pressure) of the instrument was fixed to 6 mbar.

\section{Isothermal Titration Calorimetry (ITC)}

The binding of $\mathrm{NC}, \mathrm{NC}(1-55) \mathrm{S} 3$ and $\mathrm{NC}(11-55)$ to calixarenes was investigated by Isothermal Titration Calorimetry (ITC), using a Nano ITC microcalorimeter (TA
Instruments) at $20^{\circ} \mathrm{C}$, in Tris- $\mathrm{HCl}(25 \mathrm{mM}, \mathrm{pH} 7.5)$ containing $0.2 \mathrm{mM} \mathrm{MgCl}_{2}$ and $10,30,50$ or $100 \mathrm{mM} \mathrm{NaCl}$. The titration experiments were performed by incremental injections (each 200 or $300 \mathrm{~s})$ of $2.5 \mu \mathrm{L}$ aliquots of calixarene solutions $(100$, 150 or $200 \mu \mathrm{M}$ )in $300 \mu \mathrm{L}$ of a $8 \mu \mathrm{M}$ peptide solution contained in the reaction cell. The heat flow $\left(\mu \mathrm{cal} \times \mathrm{s}^{-1}\right)$ resulting from the interaction between the two partners was continuously recorded. The quantity of heat $Q$ accompanying each injection was integrated over time and corrected for the heat of dilution measured in an independent experiment in which the calixarene solution was injected into the buffer alone. Instrument control, data acquisition, and analysis were done with the NanoAnalyze software provided by the manufacturer. Assuming 1:1 binding stoichiometry, the molar heat of binding $\Delta H^{0}$ and the binding dissociation constant $K_{d}$ were obtained by fitting the differential heat $d Q / d X_{t o t}{ }^{106}$ as a function of the total calixarene concentration $\left([\mathrm{Cal}]_{t o t}\right)$ to equation (5):

$$
\frac{1}{V_{0}\left(\frac{d Q}{d X_{\text {tot }}}\right)}=\Delta H^{0}\left(\frac{1}{2}+\frac{1-\frac{(1+r)}{2}-X_{r} / 2}{\left(X_{r}^{2}-2 X_{r}(1-r)+(1+r)^{2}\right)^{1 / 2}}\right)
$$

with $1 / r=[\mathrm{Cal}]_{\text {tot }} K_{d}, \mathrm{Xr}=X_{\text {tot }}[\mathrm{Cal}]_{t o t}$ and $X_{\text {tot }}$ is the peptide concentration in the reaction cell of volume $V_{0}$.

\section{Molecular Dynamics (MD) simulations}

The ionization state of calixarenes was investigated by QUACPAC from OpenEye, version 1.7.0.2 (https://www.eyesopen.com/quacpac). Partial charges were then assigned at the am1-bcc level by antechamber from Amber $12^{107,108}$. The full length NC from the NMR structure of its complex with a small molecule (PDB: 2M3Z) ${ }^{98}$ was used as starting point in MD simulations after removal of the bound ligand. MD simulations were performed with Amber12. The ff12SB force field was used together with custom force field parameters for $\mathrm{Zn}$-binding residues and coordinated $\mathrm{Zn}$ ions, as described previously ${ }^{17}$. A time step of 2 fs was used. $\mathrm{C}-\mathrm{H}$ bonds were restrained by the SHAKE algorithm. For each system studied in this work, one molecule of $\mathrm{NC}$ and one molecule of calixarene were placed in a rectilinear box of TIP3P water molecules at a random distance higher than $40 \AA$ from each other. Neutrality of the system was achieved by adding the proper number of $\mathrm{Na}^{+}$counter-ions. Each solvated system was then submitted to a two-step energy minimization. In the first step, water molecules were minimized around the frozen solute (NC + calixarene), while in the second step the solvated solute was energy minimized until convergence $(\mathrm{rmsd}=0.05)$. Each system was then heated up to $300 \mathrm{~K}$ during $55 \mathrm{ps}$ in the NVT ensemble and then equilibrated in density for $110 \mathrm{ps}$ at constant pressure. After these steps, unrestrained MD trajectories were produced for $0.5 \mu \mathrm{s}$ in the NPT ensemble. Four replicas of MD trajectories of $0.5 \mu \mathrm{s}$ each were run to enhance statistical significance. Analysis of MD trajectories was performed with cpptraj $^{109}$. Electrostatic surface potential was calculated by the APBS program ${ }^{110}$.

Cell-based antiviral assay with replicationdefective HIV pseudoparticles 
1 This assay (described in supplementary information) is based 2 on the infection of Hela cells by replication-defective HIV 3 particles pseudotyped with the Vesicular Stomatitis Virus 4 glycoprotein ${ }^{111}$ that bypass entry and mimic the early steps of 5 the HIV virus infection cycle (post-entry to integration).

6 For each tested calixarene, the percentage of inhibition (\%inh)

7 was calculated with :

8

$\%$ inh $=\frac{(\text { Controlluciferasevalue })-(\text { Sampleluciferasevalue })}{(\text { Controlluciferasevalue })} \times 100$

Each concentration of compound was tested in sextuplicate. The reverse transcriptase inhibitor AZT $(1 \mu \mathrm{M})$ was used as a positive control. To determine the $I C_{50}$ values, we plotted the percentage of inhibition against the calixarene concentration and fitted it with the dose-response equation (4).

In parallel to the infectivity test, the cytotoxicity of the molecules was quantified in a MTT assay (3-(4,5dimethylthiazol-2-yl)-2,5-diphenyl tetrazolium bromide $)^{112}$. Another plate of HeLa cells was thus prepared and treated in the same conditions as for the infectivity assay. $24 \mathrm{~h}$ after infection, the medium was replaced by a mix containing 100 $\mu \mathrm{L}$ of DMEM and $10 \mu \mathrm{L}$ of $12 \mathrm{mM}$ MTT solution in PBS and cells were incubated during $4 \mathrm{~h}$. In order to dissolve the insoluble purple formazan reduced by living cells, $85 \mu \mathrm{L}$ of the mix was replaced by $50 \mu \mathrm{L}$ of DMSO and gently shaken for $10 \mathrm{~min}$. The absorbance was then measured at $540 \mathrm{~nm}$ in a spectrophotometer (Safas, Monaco) and expressed in percentage of cytotoxicity, using the DMEM + DMSO solution as the control.

\section{Cell-based antiviral assay with replication competent HIV-1 strains}

The antiviral activity of calixarene CIP201 was evaluated by measuring its $I C_{50}$ values against the HIV-1 wild-type reference strain NL4-3 and a panel of viruses with resistance mutations to approved HIV-1 drugs (supplementary data, Table S1) in a TZM-bl cell line based phenotypic assay ${ }^{113}$. TZM-bl cells are characterized by luciferase and $\beta$ galactosidase reporter genes integrated in the cell genome under the control of an HIV-1 LTR promoter. The expression of reporter genes is regulated by the viral Tat protein, which is produced following transcription of the integrated provirus. Since the NC viral protein is thought to be involved in both early and late events of HIV-1 life cycle, we adopted a reinfection assay, named BiCycle Assay, consisting in a first cycle of replication in the T-cell derived MT-2 cell line followed by an additional round of replication in TZM-bl cells. MT-2 cells were seeded at a concentration of 50,000 cells/well in a 96-well plate and infected with the viruses at multiplicity of infection (M.O.I.) 0.1 in the presence of fivefold dilutions of the compounds. After $48-72 \mathrm{~h}, 50 \mu \mathrm{L}$ of supernatant from each well, containing the virus produced in the first round of infection, were used to infect TZM-bl cells seeded in a 96-plate well at a concentration of 30,000 cells/well. Two days later, cells were lysed by adding $40 \mu \mathrm{L}$ of Glo Lysis Buffer (Promega) in each well for 5 min, then 40 $\mu \mathrm{L}$ of Bright-Glo Luciferase Reagent (Promega) were added to each well for relative luminescence units (RLU) counting using a Glo-Max Multi Detection System (Promega). RLU values from each well were used to calculate the $I C_{50}$ value of each compound using the GraphPad v6.0 software. The inhibition of the early events of viral replication was evaluated through a single cycle replication assay in TZM-bl cells, named MonoCycle Assay. The method consists in the infection of TZM-bl cells at M.O.I. 0.1 in presence of serial five-fold dilutions of the drugs, similarly to the first round of infection of BiCycle Assay. After 48 hours, RLUs were counted and $I C_{50}$ values were calculated using the GraphPad software. The reference drug-resistant viruses were obtained through the NIH AIDS Reagent Program (ARP, www.aidsreagent.org) and have been already characterized by the Phenosense Assay (Monogram Biosciences), considered as the reference assay for phenotypic investigation of HIV

74 drug resistance due to its consistent application in clinical 75 trials. The infectious clones were firstly transfected in $293 \mathrm{LX}$

76 cells and then expanded in MT-2 cells.

\section{Impact of CIP201 in the production of viral 78 nucleic acid intermediates}

79 The mechanism of action of calixarene CIP201 was evaluated 80 through the quantification of viral nucleic acid intermediates 81 produced during HIV-1 replication in cell culture. MT-2 cells 82 were infected with NL4-3 wild-type strain at M.O.I 0.1 in 83 presence of $100 \mu \mathrm{M}$ of CIP201, or the reference integrase 84 inhibitor raltegravir, the protease inhibitor darunaviror the 85 reverse transcriptase inhibitor rilpivirine, all at $2 \mu \mathrm{M}$. The 86 amount of viral cDNA produced after reverse transcription 87 was quantified through a real time PCR targeting the LTR 88 region at $16 \mathrm{~h}$ post infection, while 2-LTR circles and 89 intracellular viral polyadenylated RNA transcripts were 90 quantified with a specific real time protocol at $30 \mathrm{~h}$ post 91 infection. Each of the three HIV-1 nucleic acids species was 92 measured in two separate experiments and the values obtained 93 with CIP201 were compared pairwise with the values 94 obtained with each of the reference drugs considered, by 95 Student t test.

\section{SUPPLEMENTARY DATA}

97 Calixarene synthesis and characterization, CIP200 and 98 CIP201 do not eject zinc from NC(11-55), Binding of 99 calixarenes to NC(11-55), Absence of interaction of CIP201 100 with cTAR Molecular dynamics, Impairment of reverse 101 transcription by CIP201, Effect of CIP201 on cell infection 102 with the pseudotyped viruses, Evaluation of CIP201 in NSG 103 humanized mice infected with HIV-1, Antiviral assay with 104 replication-defective HIV pseudoparticles, Description of 105 HIV-1 resistant strains.

\section{FUNDING}

107 This work was supported by the European Project THINPAD 108 "Targeting theHIV-1 Nucleocapsid Protein to fight 109 Antiretroviral Drug Resistance", FP7 Grant Agreement 110 601969, by the Agence Nationale de la Recherche (ANR) and 111 the French Proteomic Infrastructure (ProFI, ANR-10-INBS112 08-03) and by a PhD fellowship from Institute de Recherche 113 Servierto T. Botzanowski. YM is grateful to the Institut 114 Universitaire de France (IUF) for support and providing 115 additional time to be dedicated to research.

116

\section{DEDICATION}


Authors wish to dedicate this work to their friends and 2 collaborators Prof. Maurizio Botta and Prof. Olga

Zaporozhets, who passed away prematurely in 2019.

\section{CONFLICT OF INTERESTS}

None declared

6

\section{REFERENCES}

(6) De Rocquigny, H.; Gabus, C.; Vincent, A.; Fournié-Zaluski, M. C.; Roques, B.; Darlix, J. L. Viral RNA Annealing Activities of Human Immunodeficiency Virus Type 1 Nucleocapsid Protein Require Only Peptide Domains Outside the Zinc Fingers. Proc. Natl. Acad. Sci. U. S. A. 1992, 89 (14), 6472-6476.

Bampi, C.; Jacquenet, S.; Lener, D.; Décimo, D.; Darlix, J.-L. The Chaperoning and Assistance Roles of the HIV-1 Nucleocapsid Protein in Proviral DNA Synthesis and Maintenance. Int. J. Biochem. Cell Biol. 2004, 36 (9), 1668-1686. https://doi.org/10.1016/j.biocel.2004.02. 024.

(8) Mély, Y.; De Rocquigny, H.; Morellet, N.; Roques, B. P.; Gérard, D. Zinc Binding to the HIV-1 Nucleocapsid Protein: A Thermodynamic Investigation by Fluorescence Spectroscopy. Biochemistry 1996, 35 (16), 5175-5182. https://doi.org/10.1021/bi952587d.

(9) Amarasinghe, G. K.; De Guzman, R. N.; Turner, R. B.; Chancellor, K. J.; Wu, Z. R.; Summers, M. F. NMR Structure of the HIV-1 Nucleocapsid Protein Bound to Stem-Loop SL2 of the $\Psi$-RNA Packaging Signal. Implications for Genome Recognition. J. Mol. Biol. 2000, 301 (2), 491-511. https://doi.org/10.1006/jmbi.2000.3979. (10) Beltz, H.; Clauss, C.; Piémont, E.; Ficheux, D.; Gorelick, R. J.; Roques, B.; Gabus, C.; Darlix, J.-L.; de Rocquigny, H.; Mély, Y. Structural Determinants of HIV-1 Nucleocapsid Protein for CTAR DNA Binding and Destabilization, and Correlation with Inhibition of SelfPrimed DNA Synthesis. J. Mol. Biol. 2005, 348 (5), 1113-1126. https://doi.org/10.1016/j.jmb.2005.02.04 2.

(11) Bourbigot, S.; Ramalanjaona, N.; Boudier, C.; Salgado, G. F. J.; Roques, B. P.; Mély, Y.; Bouaziz, S.; Morellet, N. How the HIV-1 Nucleocapsid Protein Binds and Destabilises the (-)Primer Binding Site During Reverse Transcription. J. Mol. Biol. 2008, 383 (5), 1112-1128. https://doi.org/10.1016/j.jmb.2008.08.04 6. 
(12) De Guzman, R. N.; Wu, Z. R.; Stalling, C. C.; Pappalardo, L.; Borer, P. N.; Summers, M. F. Structure of the HIV-1 Nucleocapsid Protein Bound to the SL3 $\Psi$-RNA Recognition Element. Science 1998, 279 (5349), 384-388. https://doi.org/10.1126/science.279.534 9.384 .

Morellet, N.; Déméné, H.; Teilleux, V.; 57 Huynh-Dinh, T.; de Rocquigny, H.; 58 Fournié-Zaluski, M.-C.; Roques, B. P. $\quad 59$ Structure of the Complex between the 60 HIV-1 Nucleocapsid Protein NCp7 and 61 the Single-Stranded Pentanucleotide 62 d(ACGCC)1. J. Mol. Biol. 1998, 283 (2), 419-434. https://doi.org/10.1006/jmbi.1998.2098.

Spriggs, S.; Garyu, L.; Connor, R.;

Summers, M. F. Potential Intra- and Intermolecular Interactions Involving the Unique-5' Region of the HIV-1 5'UTR. Biochemistry 2008, 47 (49), 13064-13073. https://doi.org/10.1021/bi8014373.

Lam, W. C.; Maki, A. H.; Casas-Finet, J. R.; Erickson, J. W.; Kane, B. P.; Sowder, R. C.; Henderson, L. E. Phosphorescence and Optically Detected Magnetic Resonance Investigation of the Binding of the Nucleocapsid Protein of the Human Immunodeficiency Virus Type 1 and Related Peptides to RNA. Biochemistry 1994, 33 (35), 10693-10700.

Mély, Y.; Piémont, E.; Sorinas-Jimeno, M.; de Rocquigny, H.; Jullian, N.;

Morellet, N.; Roques, B. P.; Gérard, D. Structural and Dynamic

Characterization of the Aromatic Amino Acids of the Human Immunodeficiency Virus Type I Nucleocapsid Protein Zinc Fingers and Their Involvement in Heterologous TRNA(Phe) Binding: A Steady-State and Time-Resolved Fluorescence Study. Biophys. J. 1993, 65 (4), 1513-1522. https://doi.org/10.1016/S00063495(93)81222-0.
(17) Mori, M.; Dietrich, U.; Manetti, F.; Botta, M. Molecular Dynamics and DFT Study on HIV-1 Nucleocapsid Protein-7 in Complex with Viral Genome. $J$. Chem. Inf. Model. 2010, 50 (4), 638650. https://doi.org/10.1021/ci100070m.

(18) Dorfman, T.; Luban, J.; Goff, S. P.; Haseltine, W. A.; Göttlinger, H. G. Mapping of Functionally Important Residues of a Cysteine-Histidine Box in the Human Immunodeficiency Virus Type 1 Nucleocapsid Protein. J. Virol. 1993, 67 (10), 6159-6169.

Mori, M.; Kovalenko, L.; Lyonnais, S.; Antaki, D.; Torbett, B. E.; Botta, M.; Mirambeau, G.; Mély, Y. Nucleocapsid Protein: A Desirable Target for Future Therapies Against HIV-1. In The Future of HIV-1 Therapeutics; Torbett, B. E., Goodsell, D. S., Richman, D. D., Eds.; Current Topics in Microbiology and Immunology; Springer International Publishing, 2015; pp 53-92. https://doi.org/10.1007/82_2015_433.

(20) Sancineto, L.; Iraci, N.; Tabarrini, O.; Santi, C. NCp7: Targeting a Multitasking Protein for nextGeneration Anti-HIV Drug Development Part 1: Covalent Inhibitors. Drug Discov. Today 2018, 23 (2), 260-271. https://doi.org/10.1016/j.drudis.2017.10. 017.

(21) Iraci, N.; Tabarrini, O.; Santi, C.; Sancineto, L. NCp7: Targeting a Multitask Protein for next-Generation Anti-HIV Drug Development Part 2. Noncovalent Inhibitors and Nucleic Acid Binders. Drug Discov. Today 2018, 23 (3), 687-695. https://doi.org/10.1016/j.drudis.2018.01. 022.

(22) Gutsche, C. D. (1998) Calixarenes Revisited, Monographs in Supramolecular Chemistry.

(23) Böhmer, V. Calixarenes, Macrocycles with (Almost) Unlimited Possibilities. Angew. Chem. Int. Ed. Engl. 1995, 34 
(7), 713-745.

https://doi.org/10.1002/anie.199507131.

Neri, P.; Sessler, J. L.; Wang, M.-X.

2016 Calixarenes and Beyond:

Switzerland.

\section{(25)}

de Fatima, A.; Fernandes, S.; Sabino, A.

Calixarenes as New Platforms for Drug

Design. Curr. Drug Discov. Technol.

2009, 6 (2), 151-170.

https://doi.org/10.2174/1570163097884

88302.

Biali, S. E. In Calixarenes and Beyond;

Springer International Publishing:

Switzerland, 2016, Pp 75-93.

Guo, D.-S.; Liu, Y. Supramolecular

Chemistry of P-Sulfonatocalix[n]Arenes and Its Biological Applications. Acc.

Chem. Res. 2014, 47 (7), 1925-1934.

https://doi.org/10.1021/ar500009g.

D’acquarica, I.; Ghirga, F.; Ingallina,

C.; Quaglio, D.; Zappia, G.; Uccello-

Barretta, G.; Balzano, F.; Botta, B. In

Calixarenes and Beyond; Springer

International Publishing: Switzerland, 2016, Pp 175-193.

Mutihac, L.; Lee, J. H.; Kim, J. S.;

Vicens, J. Recognition of Amino Acids

by Functionalized Calixarenes. Chem.

Soc. Rev. 2011, 40 (5), 2777-2796.

https://doi.org/10.1039/C0CS00005A.

(30)

Perret, F.; Coleman, A. W.

Biochemistry of Anionic

Calix[n]Arenes. Chem. Commun. 2011, 47 (26), 7303-7319.

https://doi.org/10.1039/C1CC11541C.

Mo, J.; Eggers, P. K.; Yuan, Z.; Raston,

C. L.; Lim, L. Y. Paclitaxel-Loaded

Phosphonated Calixarene Nanovesicles

as a Modular Drug Delivery Platform.

Sci. Rep. 2016, 6, 23489.

https://doi.org/10.1038/srep23489.

Rodik, R. V.; Klymchenko, A. S.; Jain,

N.; Miroshnichenko, S. I.; Richert, L.;

Kalchenko, V. I.; Mély, Y. Virus-Sized

DNA Nanoparticles for Gene Delivery

Based on Micelles of Cationic

Calixarenes. Chem. - Eur. J. 2011, 17

(20), 5526-5538. https://doi.org/10.1002/chem.20110015

4.

D’acquarica, I.; Ghirga, F.; Quaglio, D.; Cerreto, A.; Ingallina, C.; Tafi, A.;

Botta, B. Molecular Recognition of

Natural Products by Resorc[4]Arene

Receptors. Curr. Pharm. Des. 2016, 22, 1715-1729.

(34) Giuliani, M.; Morbioli, I.; Sansone, F.; Casnati, A. Moulding Calixarenes for Biomacromolecule Targeting. Chem. Commun. 2015, 51 (75), 14140-14159. https://doi.org/10.1039/C5CC05204A.

(35) Yousaf, A.; Hamid, S. A.; Bunnori, N. M.; Ishola, A. Applications of Calixarenes in Cancer Chemotherapy: Facts and Perspectives. Drug Des. Devel. Ther. 2015, 9, 2831-2838. https://doi.org/10.2147/DDDT.S83213.

(36) Nimse, S. B.; Kim, T. Biological Applications of Functionalized Calixarenes. Chem. Soc. Rev. 2013, 42 (1), 366-386. https://doi.org/10.1039/c2cs35233h. (37) Hwang, K., M., Qi, Y. M., Liu, S., Y., Choy, W., Chen, J. (1994) Inhibition and Treatment of Infection by Enveloped Virus with Calix(n)Arene Compounds, In PCT Int. Appl. (Appl., P. I., Ed.), p 162, Genelabs Technologies, Inc, USA. Harris, S. J. (1995) Preparation of Calixarene-Based Compounds Having Antibacterial, Antifungal, Anticancer, and Anti-HIV Activity, In PCT Int. Appl. (Appl., P. I., Ed.), p 148, Ire. (39) Harris, S. J. (2002) Preparation of Calixarenes as Anti-Viral Compounds, In PCT Int. Appl. (Appl., P. I., Ed.), p 44, Aids Care Pharma Limited, Ire.

(40) Coveney, D., and Costello, B. (2005) Preparation of Alkylated Pyrogallol Calixarene Type Compounds as AntiViral Compounds, In U.S. Pat. Appl. Publ. (Publ., U. S. P. A., Ed.), p 13, Aids Care Pharma Limited, Ire.

(41) Srivastava, P.; Schito, M.; Fattah, R. J.; Hara, T.; Hartman, T.; Buckheit Jr., R. W.; Turpin, J. A.; Inman, J. K.; Appella, 
E. Optimization of Unique, Uncharged 50 Thioesters as Inhibitors of HIV 51 Replication. Bioorg. Med. Chem. 2004, 52 12 (24), 6437-6450.

https://doi.org/10.1016/j.bmc.2004.09.0 32.

Mourer, M.; Psychogios, N.; Laumond, G.; Aubertin, A.-M.; Regnouf-de-Vains, J.-B. Synthesis and Anti-HIV

Evaluation of Water-Soluble

Calixarene-Based Bithiazolyl Podands. Bioorg. Med. Chem. 2010, 18 (1), 36-

45.

https://doi.org/10.1016/j.bmc.2009.11.0 16.

Tsou, L. K.; Dutschman, G. E.; Gullen, E. A.; Telpoukhovskaia, M.; Cheng, Y.C.; Hamilton, A. D. Discovery of a Synthetic Dual Inhibitor of HIV and HCV Infection Based on a TetrabutoxyCalix[4]Arene Scaffold. Bioorg. Med. Chem. Lett. 2010, 20 (7), 2137-2139. https://doi.org/10.1016/j.bmcl.2010.02.0 43.

Luo, Z.-G.; Zhao, Y.; Ma, C.; Xu, X.M.; Zhang, X.-M.; Huang, N.-Y.; He, H.-Q. Synthesis and Anti-Integrase Evaluation of Novel Calix[4]Arene Derivatives Containing the Triazolyl 1,3-Diketo Moiety. Chin. Chem. Lett. 2014, 25 (5), 737-740. https://doi.org/10.1016/j.cclet.2014.03.0 12.

Rodik, R. V.; Boyko, V. I.; Kalchenko, V. I. Calixarenes in Biotechnology and Bio-Medical Researches. In Frontiers in Medicinal Chemistry; Allen B. Reitz / Atta-ur-Rahman / M. Iqbal Choudhary, 2016; Vol. 8, pp 206-301.

Luo, Z.; Zhao, Y.; Ma, C.; Li, Z.; Xu, X.; Hu, L.; Huang, N.; He, H. Synthesis, Biological Evaluation and Molecular Docking of Calix[4]Arene-Based BDiketo Derivatives as HIV-1 Integrase Inhibitors. Arch. Pharm. (Weinheim) 2015, 348 (3), 206-213. https://doi.org/10.1002/ardp.201400390.
Luo, Z.; Xu, X.; Zhang, X.; Hu, L.

Development of Calixarenes,
Cyclodextrins and Fullerenes as New Platforms for Anti-HIV Drug Design: An Overview. Mini Rev. Med. Chem. 2013, 13 (8), 1160-1165.

Kral, V., Cigler, P., Konvalinka, J., Kozisek, M., Prejdova, J., Gruener, B., Plesek, J., Lepsik, M., Pokorna, J., Kraeusslich, H.-G., and Bodem, J. (2005) Preparation and HIV Protease Inhibitory Activity of Novel Mono- and Dinuclear Cobalt Dicarbollides, In PCT Int. Appl. (Appl., P. I., Ed.), p 70, Vysoka Skola Chemicko-Technologicka V Praze, Czech Rep.; Ustav Organicke Chemie A Biochemie Av Cz; Ustav Anorganicke Chemie Av Cz; Department of Virology, University of Heidelberg.

\section{(49) Markovsky, L. N.; Kalchenko, V. I.;} Solovyov, A.; Finocchiaro, P.; Failla, S.; Atamas, L. I.; Consiglio, G.; Tsymbal, I. Upper rim alpha-hydroxy- or alphaamino phosphonic acid derivatives of calix[4]arenes., Anales de Quimica. An. Quimica 94, 164.

(50) Solovyov, A.; Cherenok, S.; Tsymbal, I.; Failla, S.; Consiglio, G. A.; Finocchiaro, P.; Kalchenko, V. Calix[4]Arenes Bearing A-amino- or Ahydroxyphosphonic Acid Fragments at the Upper Rim. Heteroat. Chem. 2001, 12 (2), 58-67. https://doi.org/10.1002/hc.2. (51) Cherenok, S. O.; Yushchenko, O. A.; Tanchuk, V. Y.; Mischenko, I. M.; Samus, N. V.; Ruban, O. V.; Matvieiev, Y. I.; Karpenko, J. A.; Kukhar, V. P.; Vovk, A. I.; et al. Calix[4]Arene- $\alpha-$ Hydroxyphosphonic Acids.Synthesis, Stereochemistry, and Inhibition of Glutathione S-Transferase. ARKIVOC 2012, 2012 (4), 278-298. https://doi.org/10.3998/ark.5550190.001 3.421 .

Vovk, A. I.; Kalchenko, V. I.;

Cherenok, S. A.; Kukhar, V. P.; Muzychka, O. V.; Lozynsky, M. O. Calix[4]Arene Methylenebisphosphonic Acids as Calf Intestine Alkaline 
Phosphatase Inhibitors. Org. Biomol. $\quad 50$

Chem. 2004, 2 (21), 3162-3166. 51

https://doi.org/10.1039/B409526J. 52

Lugovskoy, E. V.; Gritsenko, P. G.;

Koshel, T. A.; Koliesnik, I. O.;

Cherenok, S. O.; Kalchenko, O. I.;

Kalchenko, V. I.; Komisarenko, S. V.

Calix[4]Arene Methylenebisphosphonic

Acids as Inhibitors of Fibrin

Polymerization. FEBS J. 2011, 278 (8), 1244-1251.

https://doi.org/10.1111/j.1742-

4658.2011.08045.x.

Poon, D. T.; Wu, J.; Aldovini, A.

Charged Amino Acid Residues of

Human Immunodeficiency Virus Type 1

Nucleocapsid P7 Protein Involved in

RNA Packaging and Infectivity. $J$.

Virol. 1996, 70 (10), 6607-6616.

Wu, H.; Mitra, M.; Naufer, M. N.;

McCauley, M. J.; Gorelick, R. J.;

Rouzina, I.; Musier-Forsyth, K.;

Williams, M. C. Differential

Contribution of Basic Residues to HIV-

1 Nucleocapsid Protein's Nucleic Acid

Chaperone Function and Retroviral

Replication. Nucleic Acids Res. 2014, 42

(4), 2525-2537.

https://doi.org/10.1093/nar/gkt1227.

Shvadchak, V.; Sanglier, S.; Rocle, S.;

Villa, P.; Haiech, J.; Hibert, M.; Van

Dorsselaer, A.; Mély, Y.; de Rocquigny,

H. Identification by High Throughput

Screening of Small Compounds

Inhibiting the Nucleic Acid

Destabilization Activity of the HIV-1

Nucleocapsid Protein. Biochimie 2009,

91 (7), 916-923.

https://doi.org/10.1016/j.biochi.2009.04.

014.

Darlix, J.-L.; Godet, J.; Ivanyi-Nagy, R.;

Fossé, P.; Mauffret, O.; Mély, Y.

Flexible Nature and Specific Functions of the HIV-1 Nucleocapsid Protein. $J$.

Mol. Biol. 2011, 410 (4), 565-581. https://doi.org/10.1016/j.jmb.2011.03.03 7.
Sto

Stoylova, E.; De Rocquigny, H.;
Roques, B. P.; Gérard, D.; Mély, Y. Ordered Aggregation of Ribonucleic Acids by the Human Immunodeficiency Virus Type 1 Nucleocapsid Protein. Biopolymers 1997, 41 (3), 301-312. https://doi.org/10.1002/(SICI)10970282(199703)41:3<301::AIDBIP5>3.0.CO;2-W.

Bernacchi, S.; Stoylov, S.; Piémont, E.; Ficheux, D.; Roques, B. P.; Darlix, J. L.; Mély, Y. HIV-1 Nucleocapsid Protein Activates Transient Melting of Least Stable Parts of the Secondary Structure of TAR and Its Complementary Sequence1. J. Mol. Biol. 2002, 317 (3), 385-399. https://doi.org/10.1006/jmbi.2002.5429. (60) McGovern, R. E.; Fernandes, H.; Khan, A. R.; Power, N. P.; Crowley, P. B. Protein Camouflage in Cytochrome cCalixarene Complexes. Nat. Chem. 2012, 4 (7), 527-533. https://doi.org/10.1038/nchem.1342. (61) Godet, J.; de Rocquigny, H.; Raja, C.; Glasser, N.; Ficheux, D.; Darlix, J.-L.; Mély, Y. During the Early Phase of HIV-1 DNA Synthesis, Nucleocapsid Protein Directs Hybridization of the TAR Complementary Sequences via the Ends of Their Double-Stranded Stem. $J$. Mol. Biol. 2006, 356 (5), 1180-1192. https://doi.org/10.1016/j.jmb.2005.12.03 8.

(62) Vo, M.-N.; Barany, G.; Rouzina, I.; Musier-Forsyth, K. HIV-1 Nucleocapsid Protein Switches the Pathway of Transactivation Response Element RNA/DNA Annealing from Loop-Loop "Kissing" to "Zipper." J. Mol. Biol. 2009, 386 (3), 789-801. https://doi.org/10.1016/j.jmb.2008.12.07 0 .

(63) Avilov, S. V.; Boudier, C.; Gottikh, M.; Darlix, J.-L.; Mély, Y. Characterization of the Inhibition Mechanism of HIV-1 Nucleocapsid Protein Chaperone Activities by Methylated Oligoribonucleotides. Antimicrob. Agents Chemother. 2012, 56 (2), 1010- 
1018.

https://doi.org/10.1128/AAC.05614-11.

Vercruysse, T.; Basta, B.; Dehaen, W.; 52

Humbert, N.; Balzarini, J.; Debaene, F.; 53

Sanglier-Cianférani, S.; Pannecouque, $\quad 54$

C.; Mély, Y.; Daelemans, D. A Phenyl- 55

Thiadiazolylidene-Amine Derivative $\quad 56$

Ejects Zinc from Retroviral 57

Nucleocapsid Zinc Fingers and 58

Inactivates HIV Virions. Retrovirology 59

2012, 9, 95.

https://doi.org/10.1186/1742-4690-9-95. 61

Mori, M.; Schult-Dietrich, P.;

Szafarowicz, B.; Humbert, N.; Debaene, 63

F.; Sanglier-Cianferani, S.; Dietrich, U.; 64

Mély, Y.; Botta, M. Use of Virtual 65

Screening for Discovering Antiretroviral 66

Compounds Interacting with the HIV-1 67

Nucleocapsid Protein. Virus Res. 2012, 68

169 (2), 377-387.

https://doi.org/10.1016/j.virusres.2012.0 70

5.011 .

(66)

Mori, M.; Nucci, A.; Lang, M. C. D.; 72

Humbert, N.; Boudier, C.; Debaene, F.; 73

Sanglier-Cianferani, S.; Catala, M.; $\quad 74$

Schult-Dietrich, P.; Dietrich, U.; et al. $\quad 75$

Functional and Structural 76

Characterization of 2-Amino-4-

Phenylthiazole Inhibitors of the HIV-1 78

Nucleocapsid Protein with Antiviral 79

Activity. ACS Chem. Biol. 2014, 9 (9), 80

1950-1955.

https://doi.org/10.1021/cb500316h.

(67)

Record, M. T.; Lohman, T. M.; Haseth,

P. de. Ion Effects on Ligand-Nucleic

Acid Interactions. J. Mol. Biol. 1976,

107 (2), 145-158.

https://doi.org/10.1016/S0022-

2836(76)80023-X.

(68)

Mély, Y.; Rocquigny, H. de; Sorinas-

Jimeno, M.; Keith, G.; Roques, B. P.;

Marquet, R.; Gérard, D. Binding of the

HIV-1 Nucleocapsid Protein to the

Primer TRNA, InVitro, Is Essentially

Not Specific. J. Biol. Chem. 1995, 270

(4), 1650-1656.

https://doi.org/10.1074/jbc.270.4.1650. 96

(69)
Vuilleumier, C.; Bombarda, E.;

Morellet, N.; Gérard, D.; Roques, B. P.;
Mély, Y. Nucleic Acid Sequence

Discrimination by the HIV-1

Nucleocapsid Protein NCp7: A

Fluorescence Study. Biochemistry 1999 , 38 (51), 16816-16825.

https://doi.org/10.1021/bi991145p.

(70)

Zielenkiewicz, W.; Marcinowicz, A.;

Poznański, J.; Cherenok, S.; Kalchenko,

V. Calorimetric, NMR, and UV

Investigations of Aliphatic 1-Amino

Acids Complexation by Calix [4]Arene

Bis-Hydroxymethylphosphous Acid. $J$.

Incl. Phenom. Macrocycl. Chem. 2006,

55 (1-2), 11-19.

https://doi.org/10.1007/s10847-005-

9012-y.

(71) Kalchenko, O.; Cherenok, S.;

Yushchenko, O.; Kalchenko, V.

Complexation of

Calix[4]Arenehydroxymethylphosphoni

c Acids with Amino Acids. Binding

Constants Determination of the

Complexes by HPLC Method. J. Incl.

Phenom. Macrocycl. Chem. 2013, 76

(1-2), 29-36.

https://doi.org/10.1007/s10847-012-

0169-x.

(72) Talotta, C.; Gaeta, C.; Neri, P. Endo-

Complexation of Alkylammonium Ions

by Calix[4]Arene Cavity: Facilitating

Cation $-\pi$ Interactions through the

Weakly Coordinating Anion Approach.

J. Org. Chem. 2014, 79 (20), 9842-

9846.

https://doi.org/10.1021/jo5016689.

Daze, K. D.; Hof, F. The Cation- $\pi$

Interaction at Protein-Protein

Interaction Interfaces: Developing and

Learning from Synthetic Mimics of

Proteins That Bind Methylated Lysines.

Acc. Chem. Res. 2013, 46 (4), 937-945.

https://doi.org/10.1021/ar300072g.

(74) Mori, M.; Manetti, F.; Botta, M.

Predicting the Binding Mode of Known

NCp7 Inhibitors To Facilitate the

Design of Novel Modulators. J. Chem.

Inf. Model. 2011, 51 (2), 446-454.

https://doi.org/10.1021/ci100393m. 
(75) Doyle, M. L.; Ladbury, J. E. 50

Biocalorimetry 2 : applications of 51

calorimetry in the biological sciences - $\quad 52$

Colby College Libraries

http://link.colby.edu/portal/Biocalorimet

ry-2--applications-of-calorimetry-in/q-

0LC2F9Ito/ (accessed May 13, 2019).

(76)

Sharma, K. K.; Przybilla, F.; Restle, T.;

Boudier, C.; Godet, J.; Mély, Y. Reverse

Transcriptase in Action: FRET-Based

Assay for Monitoring Flipping and

Polymerase Activity in Real Time. Anal.

Chem. 2015, 87 (15), 7690-7697.

https://doi.org/10.1021/acs.analchem.5b 01126.

Althaus, I. W.; Chou, J. J.; Gonzales, A. J.; Deibel, M. R.; Chou, K. C.; Kezdy, F. J.; Romero, D. L.; Aristoff, P. A.; Tarpley, W. G.; Reusser, F. Steady-State Kinetic Studies with the Non-

Nucleoside HIV-1 Reverse

Transcriptase Inhibitor U-87201E. J.

Biol. Chem. 1993, 268 (9), 6119-6124.

Althaus, I. W.; Chou, J. J.; Gonzales, A. 73

J.; Deibel, M. R.; Chou, K. C.; Kezdy, 74

F. J.; Romero, D. L.; Palmer, J. R.; 75

Thomas, R. C. Kinetic Studies with the 76

Non-Nucleoside HIV-1 Reverse 77

Transcriptase Inhibitor U-88204E. 78

Biochemistry 1993, 32 (26), 6548-6554. 79

https://doi.org/10.1021/bi00077a008. 80

(79) Amand, M.; Iserentant, G.; Poli, A.; 81

Sleiman, M.; Fievez, V.; Sanchez, I. P.; 82

Sauvageot, N.; Michel, T.; Aouali, N.; 83

Janji, B.; et al. Human 84

CD56dimCD16dim Cells As an 85

Individualized Natural Killer Cell $\quad 86$

Subset. Front. Immunol. 2017, 8. 87

https://doi.org/10.3389/fimmu.2017.006 88

99.

(80)

De Rocquigny, H.; Shvadchak, V.;

Avilov, S.; Dong, C. Z.; Dietrich, U.;

Darlix, J.-L.; Mély, Y. Targeting the

Viral Nucleocapsid Protein in Anti-

HIV-1 Therapy. Mini Rev. Med. Chem.

2008, 8, 24-35.

(81)
Trotter, J.; Torbett, B. E. A Cleavage

Enzyme-Cytometric Bead Array

73

75

77

(85)

81

3

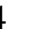

87

Provides Biochemical Profiling of Resistance Mutations in HIV-1 Gag and Protease. Biochemistry 2011, 50 (20), 4371-4381. https://doi.org/10.1021/bi200031m. 82) Cimarelli, A.; Sandin, S.; Höglund, S.; Luban, J. Basic Residues in Human Immunodeficiency Virus Type 1 Nucleocapsid Promote Virion Assembly via Interaction with RNA. J. Virol. 2000, 74 (7), 3046-3057. https://doi.org/10.1128/JVI.74.7.30463057.2000.

(83) Dussupt, V.; Sette, P.; Bello, N. F.; Javid, M. P.; Nagashima, K.; Bouamr, F. Basic Residues in the Nucleocapsid Domain of Gag Are Critical for Late Events of HIV-1 Budding. J. Virol. 2011, 85 (5), 2304-2315. https://doi.org/10.1128/JVI.01562-10.

(84) Rice, W. G.; Schaeffer, C. A.; Harten, B.; Villinger, F.; South, T. L.; Summers, M. F.; Henderson, L. E.; Bess, J. W.; Arthur, L. O.; McDougal, J. S.; et al. Inhibition of HIV-1 Infectivity by ZincEjecting Aromatic C-Nitroso Compounds. Nature 1993, 361 (6411), 473-475. https://doi.org/10.1038/361473a0. Rice, W. G.; Supko, J. G.; Malspeis, L.; Buckheit, R. W.; Clanton, D.; Bu, M.; Graham, L.; Schaeffer, C. A.; Turpin, J. A.; Domagala, J.; et al. Inhibitors of HIV Nucleocapsid Protein Zinc Fingers as Candidates for the Treatment of AIDS. Science 1995, 270 (5239), 11941197. https://doi.org/10.1126/science.270.523 9.1194.

(86) Witvrouw, M.; Balzarini, J.; Pannecouque, C.; Jhaumeer-Laulloo, S.; Esté, J. A.; Schols, D.; Cherepanov, P.; Schmit, J. C.; Debyser, Z.; Vandamme, A. M.; et al. SRR-SB3, a DisulfideContaining Macrolide That Inhibits a Late Stage of the Replicative Cycle of Human Immunodeficiency Virus. Antimicrob. Agents Chemother. 1997, 41 (2), 262-268. 
Turpin, J. A.; Song, Y.; Inman, J. K.;

Huang, M.; Wallqvist, A.; Maynard, A.; Covell, D. G.; Rice, W. G.; Appella, E. Synthesis and Biological Properties of

Novel Pyridinioalkanoyl Thiolesters (PATE) as Anti-HIV-1 Agents That Target the Viral Nucleocapsid Protein Zinc Fingers. J. Med. Chem. 1999, 42 (1), 67-86. https://doi.org/10.1021/jm9802517.

Bombarda, E.; Morellet, N.; Cherradi, H.; Spiess, B.; Bouaziz, S.; Grell, E.; Roques, B. P.; Mély, Y. Determination of the PKa of the Four $\mathrm{Zn} 2+-$

Coordinating Residues of the Distal Finger Motif of the HIV-1 Nucleocapsid Protein: Consequences on the Binding of Zn2+1. J. Mol. Biol. 2001, 310 (3), 659-672. https://doi.org/10.1006/jmbi.2001.4770.

Huang, M.; Maynard, A.; Turpin, J. A.; Graham, L.; Janini, G. M.; Covell, D. G.; Rice, W. G. Anti-HIV Agents That Selectively Target Retroviral Nucleocapsid Protein Zinc Fingers without Affecting Cellular Zinc Finger Proteins. J. Med. Chem. 1998, 41 (9), 1371-1381. https://doi.org/10.1021/jm9708543. Jenkins, L. M. M.; Hara, T.; Durell, S. R.; Hayashi, R.; Inman, J. K.; Piquemal, J.-P.; Gresh, N.; Appella, E. Specificity of Acyl Transfer from 2-

Mercaptobenzamide Thioesters to the HIV-1 Nucleocapsid Protein. J. Am. Chem. Soc. 2007, 129 (36), 1106711078. https://doi.org/10.1021/ja071254o.

Jenkins, L. M. M.; Ott, D. E.; Hayashi, R.; Coren, L. V.; Wang, D.; Xu, Q.; Schito, M. L.; Inman, J. K.; Appella, D. H.; Appella, E. Small-Molecule Inactivation of HIV-1 NCp7 by Repetitive Intracellular Acyl Transfer. Nat. Chem. Biol. 2010, 6 (12), 887-889. https://doi.org/10.1038/nchembio.456.
Buckheit, R. W.; et al. Inhibition of Multiple Phases of Human Immunodeficiency Virus Type 1 Replication by a Dithiane Compound That Attacks the Conserved Zinc Fingers of Retroviral Nucleocapsid Proteins. Antimicrob. Agents Chemother. 1997, 41 (2), 419-426.

Rice, W. G.; Turpin, J. A.; Huang, M.; Clanton, D.; Buckheit, R. W.; Covell, D. G.; Wallqvist, A.; McDonnell, N. B.; DeGuzman, R. N.; Summers, M. F.; et al. Azodicarbonamide Inhibits HIV-1 Replication by Targeting the Nucleocapsid Protein. Nat. Med. 1997, 3 (3), 341-345. https://doi.org/10.1038/nm0397-341. (94) Pannecouque, C.; Szafarowicz, B.; Volkova, N.; Bakulev, V.; Dehaen, W.; Mély, Y.; Daelemans, D. Inhibition of HIV-1 Replication by a Bis-

Thiadiazolbenzene-1,2-Diamine That Chelates Zinc Ions from Retroviral Nucleocapsid Zinc Fingers. Antimicrob. Agents Chemother. 2010, 54 (4), 14611468.

https://doi.org/10.1128/AAC.01671-09.

(95) Goebel, F. D.; Hemmer, R.; Schmitt, J.-

C.; Bogner, J. R.; de Clercq, E.;

Witvrouw, M.; Pannecouque, C.;

Valeyev, R.; Vandevelde, M.; Margery, H.; et al. Phase I/II Dose Escalation and Randomized Withdrawal Study with Add-on Azodicarbonamide in Patients Failing on Current Antiretroviral Therapy. AIDS 2001, 15, 33-45.

(96) Breuer, S.; Chang, M. W.; Yuan, J.; Torbett, B. E. Identification of HIV-1 Inhibitors Targeting the Nucleocapsid Protein. J. Med. Chem. 2012, 55 (11), 4968-4977. https://doi.org/10.1021/jm201442t. (97) Kim, M.-J.; Kim, S. H.; Park, J. A.; Yu, K. L.; Jang, S. I.; Kim, B. S.; Lee, E. S.; You, J. C. Identification and Characterization of a New Type of Inhibitor against the Human Immunodeficiency Virus Type-1 Nucleocapsid Protein. Retrovirology 
2015, 12, 90.

https://doi.org/10.1186/s12977-0150218-9.

\section{(98)}

Goudreau, N.; Hucke, O.; Faucher, A.-

M.; Grand-Maître, C.; Lepage, O.;

Bonneau, P. R.; Mason, S. W.; Titolo, S.

Discovery and Structural

Characterization of a New Inhibitor

Series of HIV-1 Nucleocapsid Function:

NMR Solution Structure Determination

of a Ternary Complex Involving a 2:1

Inhibitor/NC Stoichiometry. J. Mol.

Biol. 2013, 425 (11), 1982-1998.

https://doi.org/10.1016/j.jmb.2013.02.02 2.

Kerns, E. H.; Di, L. Drug-like

Properties: Concepts, Structure Design and Methods; from ADME to Toxicity

Optimization ; [Metabolism, Solubility,

Pharmacokinetics, Permeability, CYP

Inhibition, Toxicity, Prodrugs];

Elsevier, Acad. Press: Amsterdam, 2008.

Stephen, A. G.; Worthy, K. M.; Towler, E.; Mikovits, J. A.; Sei, S.; Roberts, P.; Yang, Q.; Akee, R. K.; Klausmeyer, P.; McCloud, T. G.; et al. Identification of HIV-1 Nucleocapsid Protein: Nucleic Acid Antagonists with Cellular AntiHIV Activity. Biochem. Biophys. Res. Commun. 2002, 296 (5), 1228-1237. https://doi.org/10.1016/S0006291X(02)02063-6.

Tanchou, V.; Gabus, C.; Rogemond, V.; Luc Darlix, J. Formation of Stable and Functional HIV-1 Nucleoprotein Complexesin Vitro. J. Mol. Biol. 1995, 252 (5), 563-571. https://doi.org/10.1006/jmbi.1995.0520. Khan, R.; Giedroc, D. P. Recombinant Human Immunodeficiency Virus Type 1 Nucleocapsid (NCp7) Protein Unwinds TRNA. J. Biol. Chem. 1992, 267 (10), 6689-6695.

Binding Site Is Critically Dependent on the NCp7 Zinc Fingers Structure. $J$.

Biol. Chem. 1998, 273 (9), 4819-4822.

(104) de Rocquigny, H.; Ficheux, D.; Gabus, C.; Fournié-Zaluski, M.-C.; Darlix, J.-

L.; Roques, B. P. First Large Scale Chemical Synthesis of the 72 Amino Acid HIV-1 Nucleocapsid Protein NCp7 in an Active Form. Biochem. Biophys.

Res. Commun. 1991, 180 (2), 10101018. https://doi.org/10.1016/S0006291X(05)81166-0.

(105) Motulsky, H. J.; Christopoulos, A. Fitting Models to Biological Data Using Linear and Nonlinear Rgression : A Practical Guide to Curve Fitting, (Press, O. U., Ed.).; 2004.

(106) Wiseman, T.; Williston, S.; Brandts, J. F.; Lin, L.-N. Rapid Measurement of Binding Constants and Heats of Binding Using a New Titration Calorimeter. Anal. Biochem. 1989, 179 (1), 131-137. https://doi.org/10.1016/00032697(89)90213-3.

(107) Wang, J.; Wang, W.; Kollman, P. A.; Case, D. A. Automatic Atom Type and Bond Type Perception in Molecular Mechanical Calculations. J. Mol. Graph. Model. 2006, 25 (2), 247-260. https://doi.org/10.1016/j.jmgm.2005.12. 005.

(108) D.A. Case, T. A. Darden., T.E. Cheatham, III, C.L. Simmerling, J. Wang, R.E. Duke, R. Luo, R.C. Walker, W. Zhang, K.M. Merz, B. Roberts, S. Hayik, A. Roitberg, G. Seabra, J. Swails, A.W. Götz, I. Kolossváry, K.F. Wong, F. Paesani, J. Vanicek, R.M. Wolf, J. Liu, X. Wu, S.R. Brozell, T. Steinbrecher, H. Gohlke, Q. Cai, X. Ye, J. Wang, M.-J. Hsieh, G. Cui, D.R. Roe, D.H. Mathews, M.G. Seetin, R. Salomon-Ferrer, C. Sagui, V. Babin, T. Luchko, S. Gusarov, A. Kovalenko, and P.A. Kollman (2012), AMBER 12, University of California, San Francisco. J.; Roques, B. P. The Annealing of 96 (109) TRNA3Lys to Human Immunodeficiency Virus Type 1 Primer 98
Roe, D. R.; Cheatham, T. E. PTRAJ and CPPTRAJ: Software for Processing and Analysis of Molecular Dynamics 
Trajectory Data. J. Chem. Theory Comput. 2013, 9 (7), 3084-3095. https://doi.org/10.1021/ct400341p.

Dolinsky, T. J.; Nielsen, J. E.;

McCammon, J. A.; Baker, N. A. PDB2PQR: An Automated Pipeline for the Setup of Poisson-Boltzmann Electrostatics Calculations. Nucleic Acids Res. 2004, 32 (suppl_2), W665W667. https://doi.org/10.1093/nar/gkh381. 28 Mandel, R. J.; Nguyen, M.; Trono, D.; 30 Naldini, L. A Third-Generation 31 Lentivirus Vector with a Conditional 32 Packaging System. J. Virol. 1998, 72 (11), 8463-8471.
(112) Mosmann, T. Rapid Colorimetric Assay for Cellular Growth and Survival: Application to Proliferation and Cytotoxicity Assays. J. Immunol. Methods 1983, 65 (1), 55-63. https://doi.org/10.1016/00221759(83)90303-4.

(113) Saladini, F.; Giannini, A.; Boccuto, A.; Vicenti, I.; Zazzi, M. Agreement between an In-House Replication Competent and a Reference Replication Defective Recombinant Virus Assay for Measuring Phenotypic Resistance to HIV-1 Protease, Reverse Transcriptase, and Integrase Inhibitors. J. Clin. Lab. Anal. 2017, n/a-n/a. https://doi.org/10.1002/jcla.22206. 
Calixarene CIP201

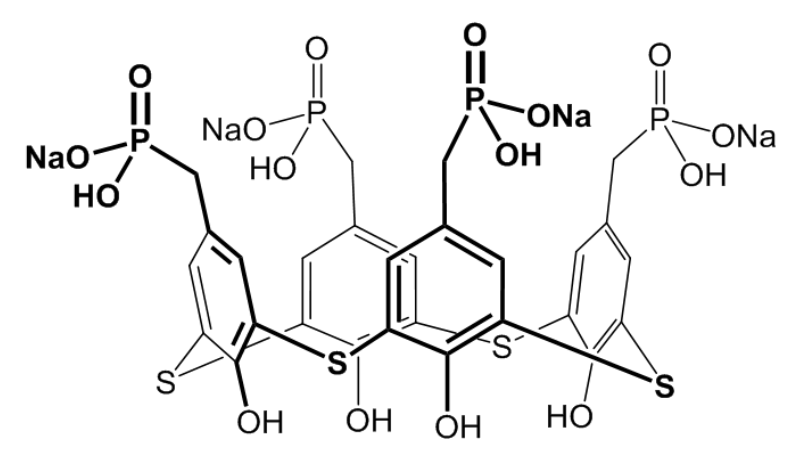

Binding model of CIP201 to the HIV-1 nucleocapsid protein NC

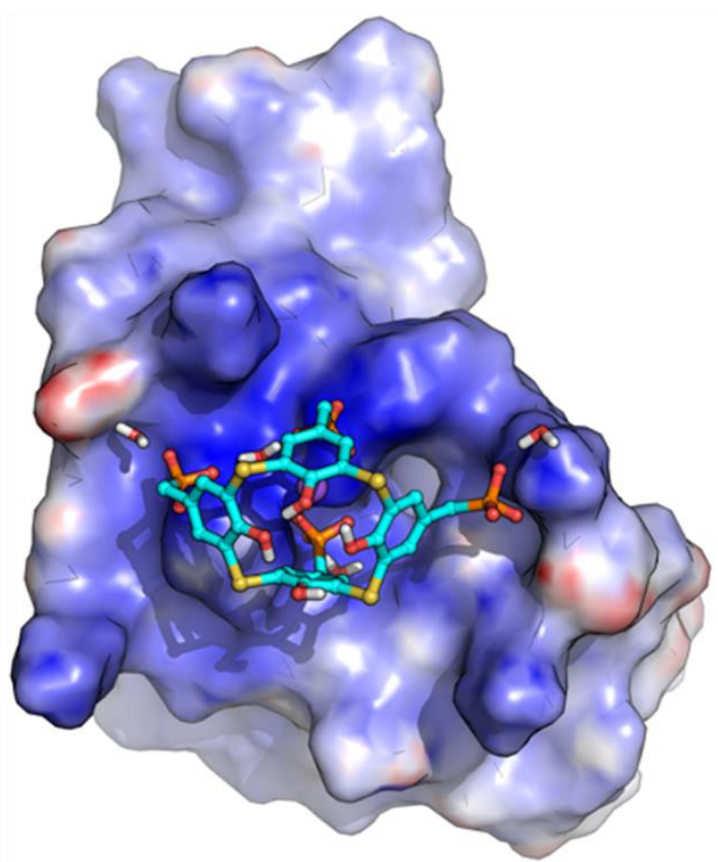

$K_{\mathrm{d}} \approx 1 \mu \mathrm{M} \Rightarrow$ blocks NC binding to nucleic acids $\Rightarrow$ antiviral activity $\left(I C_{50} \approx 1 \mu \mathrm{M}\right.$ ) with low cytotoxicity $\left(C C_{50}>5 \mathrm{mM}\right)$ on HIV-1 reference and resistant viral strains. 